\title{
STREAMLINING DIGITAL MODELING \\ AND BUILDING INFORMATION \\ MODELLING (BIM) USES FOR THE OIL \\ AND GAS PROJECTS
}

\author{
Cen-Ying Lee ${ }^{1, *}$, Heap-Yih Chong ${ }^{1}$, Xiangyu Wang ${ }^{1}$ \\ ${ }^{1}$ School of Built Environment, Curtin University, Australia \\ * cenying.lee@ postgrad.curtin.edu.au
}

Abstract

The oil and gas industry is a technology-driven industry. Over the last two (2) decades, it has heavily made use of digital modeling and associated technologies (DMAT) to enhance its commercial capability. Meanwhile, the Building Information Modelling (BIM) has grown at an exponential rate in the built environment sector. It is not only a digital representation of physical and functional characteristics of a facility, but it has also made an impact on the management processes of building project lifecycle. It is apparent that there are many similarities between BIM and DMAT usability in the aspect of physical modeling and functionality. The aim of this study is to streamline the usage of both DMAT and BIM whilst discovering valuable practices for performance improvement in the oil and gas projects. To achieve this, twenty-eight (28) BIM guidelines, eighty-three (83) DMAT academic publications and one hundred and one (101) DMAT vendor case studies were selected for review. The findings uncover (a) thirty-eight (38) BIM uses; (b) thirty-two (32) DMAT uses and; (c) thirty-six (36) both DMAT and BIM uses. The synergy between DMAT and BIM uses would render insightful references into managing efficient oil and gas's projects. It also helps project stakeholders to recognise future investment or potential development areas of BIM and DMAT uses in their projects. 
Keywords: Digital Modeling, Associated Technologies, Building Information Modeling, Streamline, Oil and Gas

\section{Introduction}

Oil and gas sector contributes significantly to more than half of humanity's primary energy supply (BHP, 2015). However, out of the total of 365 oil and gas megaprojects in the world, $73 \%$ of projects were reported schedule delays and $64 \%$ of projects experienced cost overruns $(E Y, 2014)$. One of the main factors contributed to project failures is management, contracting and project delivery strategies (Credit Suisse, 2014). It is envisaged that the technological prowess and advances should be incorporated into future oil and gas projects to embrace new thinking for performance improvement (Reid and Cann, 2016).

In the built environment sector, Building Information Modelling (BIM) is recognised as an emerging digital tool which enables information sharing of resources for a facility to form a reliable source for decision making throughout the project lifecycle (National BIM Standards, 2015). It is not only the digital representations of physical and characteristics of a facility but it is also a philosophy which transforms the way facilities are designed and managed by encouraging collaboration of all stakeholders' roles in a project (Azhar, 2011). Due to its potential values and benefits, BIM has been strongly advocated by many governments in the world. For instance, the Singapore government has mandated the implementation of BIM since 2013 (Teo et. al., 2015). The UK government also required all centrally procured public projects deploy BIM at level 2 by 2016 (HM Government, 2014). In Australia, the Federal Government's Infrastructure, Transport and Cities Parliamentary Committee has recommended that all major government infrastructure projects (over the value of $\$ 50$ million) to implement BIM (Infrastructure Australia, 2016). BIM is commonly viewed in 3D, but the model includes information used by other building analysis applications, such as energy simulation, computational fluid dynamics (CFD), day lighting, cost estimating and building code checking (GSA, 2015). BIM adoption goes beyond design and construction, and it extends to the project management and facility 
management as the files of BIM can be extracted and exchanged to support decision making in connection with a facility.

On the other hand, it has been a few decades that the oil and gas projects deployed DMAT to enhance data management and collaboration process among the interdisciplinary team. DMAT refers to 3D geometric models and/or geometric bedding models and it's associated technologies which are usually adopted by the oil and gas industry to realise its facility. DMAT in the context of this study represents a simple 3D geometric model which contains very little intelligence or it may consist of high-level intelligence that is usually organised as a prototype of the facility to perform various functions. For exploration and production, geometry 3D bedding modeling such as the reservoir modeling has been developed to improve estimation of reserves (Abdideh and Bargahi, 2012); prediction of future production (Beeson et. al., 2014); and evaluating alternative reservoir management scenarios (Tavallali and Karimi, 2016). For design, construction and operation of the oil and gas facilities, plant lifecycle management (PLM) were deployed to allow multi-disciplinary teams like piping, electrical, mechanical, civil, structural and architectural design work concurrently under a collaboration platform (Intergraph, 2016). Information extracted from a plant model can be used for procurement such as material management, strategic sourcing and contract management (Xue, 2015). Apart from geometry bedding modelling and PLM, other DMAT uses which also have similar functionality and physical attributes with the BIM such as a unified information model of oil loading station was created in Samara Oblast, Russia, which used a mobile device on site for accessing information of model and project planning (Bentley, 2015, p. 123). Both BIM and DMAT are observed to have common attributes such as both technologies create $3 \mathrm{D}$ virtual models and they could interoperate with other technologies to achieve the project outcomes.

Some BIM uses could be potentially applied in the oil and gas industry to enhance their project performance. BIM and Augmented Realty (AR) could be used for project visualisation as it allows designers and owners to gain an immersive and interactive experience (Wang et al., 2014) prior to oil and gas plant fabrication and installation. BIM and Firefly Algorithm (FA) could be integrated to automatically 
develop an optimal tower crane layout plan (Wang et al., 2015) for the oil and gas project construction. Besides, BIM and Light Detection and Ranging (LiDAR) could be developed to provide real-time information for on-site quality control (Wang et al., 2015a). Mechanical, plumbing and electrical (MEP) are essential facility elements that formed a majority components of the oil and gas plant fabrication and installation. A practical BIM framework which integrated the MEP layout from preliminary design to construction stage was formulated to resolve the design and constructability issues (Wang et al., 2016). To improve defect management practices in the oil and gas projects, BIM information could be linked with defects data effectively by converting it to RDF format and implementing SPARQL queries (Lee et al., 2016). Past oil and gas projects failed to deliver their desired outcomes due to many re-works, design errors, inefficiency in construction and life cycle performance failures. A total constraint management (TCM) framework which incorporated BIM and other related technologies was developed to improve oil and gas construction workflow and productivity (Wang et al., 2016a).

There were reviews on the BIM uses in building and infrastructure projects but none of the studies were carried out to identify BIM uses in the oil and gas industry. Twenty-four (24) industrial reports and more than forty (40) case studies in academic publications were collected and assessed to determine current BIM uses and the emerging BIM applications among the building, airports, bridges and roadworks (Shou et al., 2014). The BIM and its associated technologies applications of the road projects in Australia and China were also be compared to analyse the differences in the cultural and managerial practices between the projects in two countries (Chong et al., 2016).

Infrastructure Australia (2016) asserted that the best practices require a focus on the harmonisation which means the practices and standards have to be aligned to reduce duplication and improve delivery. To identify potential BIM applications and its associated technologies for improving oil and gas project performance, it is important to streamline both DMAT and BIM uses. The synergy between DMAT and BIM uses could create a better understanding for the oil and gas industry to plan, design, develop and operate its facilities whilst distinguish valuable key process areas be brought into the oil and gas industry for performance improvement. 
To achieve the aim, this paper outlines three objectives as follows: - (1) to synthesis BIM uses from BIM guidelines; (2) to determine DMAT uses in the oil and gas industry; and (3) to streamline BIM and DMAT uses for the oil and gas industry.

\section{BIM and DMAT Uses}

The term "uses" is originated to classify the BIM uses so that project participants who will deploy the BIM in their projects could communicate and collaborate the specific value of a particular BIM application prior to the BIM implementation. The motivation behind the identification of BIM uses is that there is no common language existed for project participants to precisely communicate the purposes among each other for implementing BIM (Kreider, 2013).

While some BIM guidelines expressed the term of BIM uses as "BIM deliverables", other guidelines used the term of "BIM applications" which in fact carry the similar meaning as the former. If we view all these terms as the synonyms of BIM uses, there are many BIM guidelines that outlined the BIM uses. However, only a few guidelines that defined the meaning of the BIM uses clearly. NATSPEC (2016) asserted that BIM uses should not link intrinsically to project phases but they should be selected to support project goals at the beginning of the project and be planned how to deploy during different project phases. The nature of BIM technology allows different stakeholders use the BIM in multiple ways depending on the specific needs they may have (NYCDDC, 2012). Hence, BIM uses could be defined as the BIM tools that are deployed to coordinate the specific purposes for realising the project objectives.

A similar rationale is applied to the DMAT uses as the ultimate goal of the oil and gas owners and/or operators are to realise a facility which would be delivered on time, within their budgets, safely, complied with the strict environmental regulations, satisfied other stakeholders and to optimise their production during operation. To achieve project outcomes, BIM and DMAT uses should be classified based on the purposes and objectives as in table 1 .

Table 1: BIM and DMAT Uses Purposes 


\begin{tabular}{|c|c|c|}
\hline BIM use purpose & BIM use objective & Synonyms \\
\hline Gather & $\begin{array}{l}\text { It captures current status of a facility, quantifies } \\
\text { the amount of a facility element, monitors the } \\
\text { information and qualifies the status of facility } \\
\text { elements. }\end{array}$ & $\begin{array}{l}\text { administer, collect, manage, acquire, } \\
\text { quantity take-off, observe, measure, } \\
\text { follow, track, identify }\end{array}$ \\
\hline Generate & $\begin{array}{l}\text { It prescribes the need for and specify facility } \\
\text { elements, arrange the placement of facility } \\
\text { elements and determines the magnitude and size } \\
\text { of facility elements. }\end{array}$ & $\begin{array}{l}\text { create, author, model, program, specify, } \\
\text { configure, lay out, locate, place, scale, } \\
\text { engineer }\end{array}$ \\
\hline Analyse & $\begin{array}{l}\text { It coordinates the relationship of facility } \\
\text { elements, forecasts the future performance of the } \\
\text { facility and validates the accuracy of the facility } \\
\text { information. }\end{array}$ & $\begin{array}{l}\text { examine, evaluate, detect, avoid, simulate, } \\
\text { predict, check, confirm }\end{array}$ \\
\hline Communicate & $\begin{array}{l}\text { It allows visualisation of a facility, transforms } \\
\text { the information to be received by another } \\
\text { process, draws a symbolic representation of the } \\
\text { facility and documents the specification of the } \\
\text { facility elements. }\end{array}$ & $\begin{array}{l}\text { exchange, review, translate, draft, } \\
\text { annotate, detail, specify, submit, schedule, } \\
\text { report }\end{array}$ \\
\hline Realise & $\begin{array}{l}\text { It facilitates the facility information for } \\
\text { fabrication, assembles the separate facility } \\
\text { elements, controls the operation of executing } \\
\text { equipment and regulates the operation of a } \\
\text { facility element. }\end{array}$ & $\begin{array}{l}\text { implement, perform, execute, } \\
\text { manufacture, prefabricate, manipulate, } \\
\text { direct }\end{array}$ \\
\hline
\end{tabular}

Note: This table is extracted from the National BIM Standard (2015)

\section{Review Methodology}

Figure 1 demonstrated a five-stage review framework which was used in this study. 
Figure 1 Five-Stage Review Framework

\section{Step 1: Problem Identification}

There is an inconsistent language of BIM and DMAT uses between the Built Environment sector and the oil and gas industry. Hence, there is a need to bridge the semantic gap of BIM and DMAT uses between these two industries to provide a better understanding for the oil and gas industry to communicate precise purpose and context of implementing these technologies for improving project performance.

\begin{tabular}{|c|c|c|c|c|}
\hline \multicolumn{5}{|c|}{ Step 2 Search for Evidence } \\
\hline Stages & \multicolumn{2}{|l|}{ Sources } & Actions & Evidences \\
\hline \multirow{2}{*}{$\begin{array}{l}\text { Stage } 1 \\
\text { Literature } \\
\text { Search }\end{array}$} & \multicolumn{2}{|c|}{ BIM guidelines } & Select & - Keyword: BIM guidelines \\
\hline & \multicolumn{2}{|c|}{$\begin{array}{l}\text { DMAT uses: } \\
\text { - Peer-reviewed Journal } \\
\text { Articles and } \\
\text { Conference Papers } \\
\text { - DMAT Vendor Case } \\
\text { Studies }\end{array}$} & Select & $\begin{array}{l}\text { - Years: 2012-2016 } \\
\text { - Keyword: 3D model oil gas }\end{array}$ \\
\hline \multirow{2}{*}{$\begin{array}{l}\text { Stage } 2 \\
\text { Literature } \\
\text { Filtration }\end{array}$} & \multicolumn{2}{|c|}{ - BIM guidelines } & Select & Discussed the BIM uses \\
\hline & \multicolumn{2}{|c|}{$\begin{array}{l}\text { - DMAT academic } \\
\text { publications (Peer- } \\
\text { Reviewed) } \\
\text { - DMT Vendor case } \\
\text { studies }\end{array}$} & Select & Discussed the DMAT uses \\
\hline \multicolumn{5}{|c|}{ Step 3 Evaluate Data (Findings) } \\
\hline \multirow{2}{*}{\multicolumn{2}{|c|}{$\begin{array}{l}\text { Sources } \\
\text { BIM guidelines }\end{array}$}} & \multicolumn{2}{|l|}{ Actions } & Evidences \\
\hline & & & & BIM Uses \\
\hline \multicolumn{2}{|c|}{$\begin{array}{l}\text { - DMAT academic } \\
\text { publications } \\
\text { - DMAT Vendor case studies }\end{array}$} & \multicolumn{2}{|c|}{ Synthesis and Tabulate } & DMAT Uses \\
\hline \multicolumn{5}{|c|}{ Step 4 Data Analysis and Discussion (Streamlining and Presentation) } \\
\hline \multirow{2}{*}{$\begin{array}{l}\text { Sources } \\
\text { - BIM Uses } \\
\text { - DMAT Uses }\end{array}$} & \multicolumn{2}{|l|}{ Actions } & \multicolumn{2}{|c|}{ Evidences } \\
\hline & \multicolumn{2}{|c|}{ Streamline and Tabulat } & \multicolumn{2}{|c|}{$\begin{array}{ll}\text { - } & \text { Streamlined BIM and DMAT Uses } \\
\text { - } & \text { Distinguished DMAT Uses } \\
\end{array}$} \\
\hline
\end{tabular}

The first step involved in this study was problem identification. Next, to identify the solution to the problem, an intensive literature search was carried out. The Google search engine was deployed to identify BIM guidelines. BIM guidelines were selected if they stated or sufficiently discussed BIM usability and its purpose. Figure 2 demonstrates the numbers of the BIM guidelines from 2012 to 2016 and also country by publications used in this study. The highest numbers of BIM 
guidelines were in the year of 2012.This may due to the rapid growth and use of BIM in the industry. The highest number of publications was recorded by the United States which consisted eighteen (18) articles. The significant high number of BIM guidelines in this country mainly due to the greater adoption and use of BIM in the country.

Figure 2: Years, numbers and country by publication of BIM guidelines

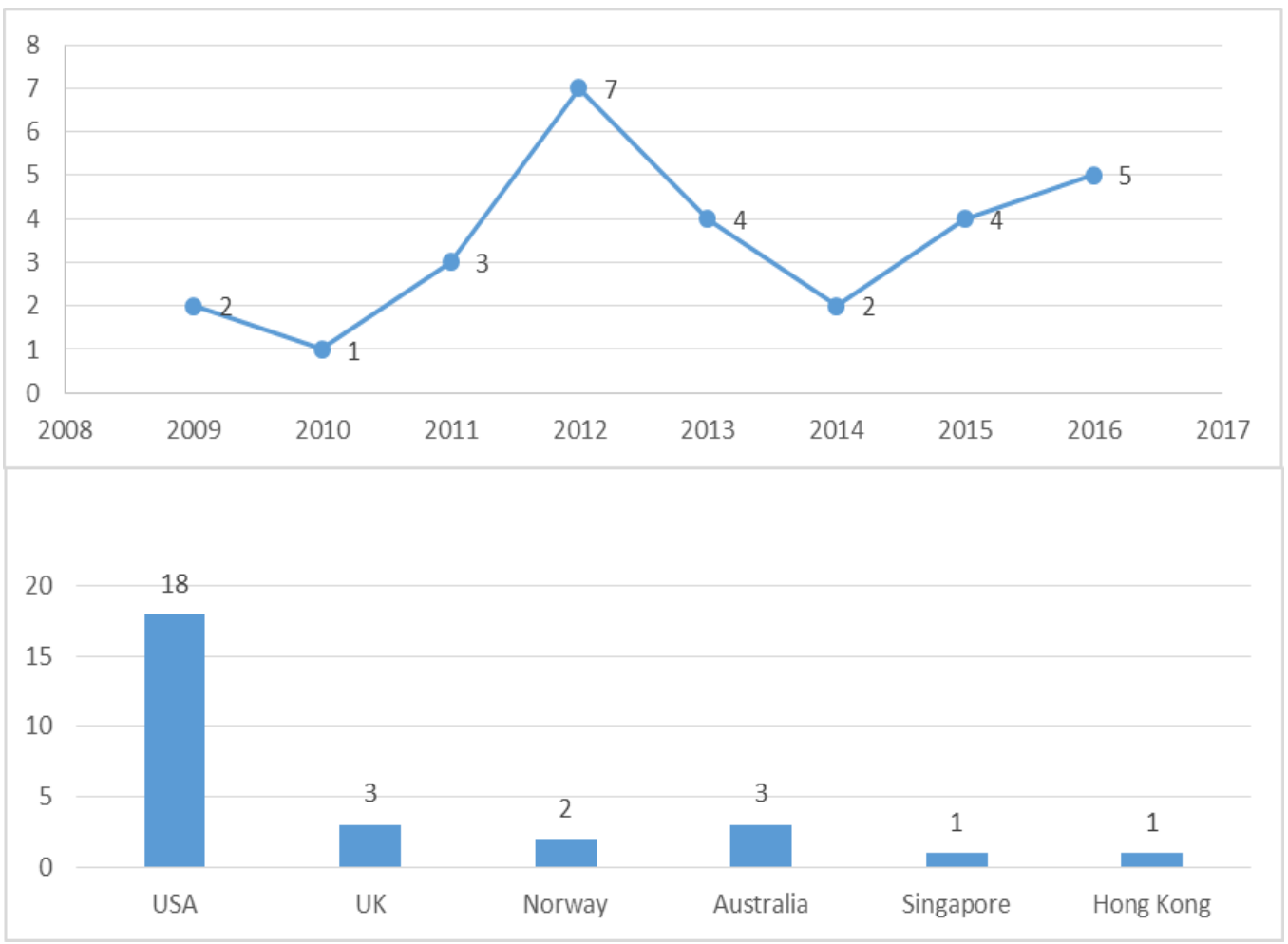

On the other hand, the usability of DMAT was determined through; (1) peerreviewed journal articles and conference papers; and (2) DMAT vendor case studies. The Google scholar was used to identify the academic publication whereas the Google search engine was deployed to identify DMAT objective by DMAT vendors. Some of the common DMAT vendors selected in this study were as follows:-

Table 2: List of Common DMAT vendors selected

\begin{tabular}{|l|l|}
\hline Disciplines & DMAT Vendors \\
\hline Exploration and Production & Schlumberger, Landmark, Paradigm, Petex \\
\hline Design, Procure and Construct & $\begin{array}{l}\text { Bentley, Autodesk, Synchro, AVEVA (formerly known as PDMS and } \\
\text { Tribon), Intergraph, Tekla, Aspentech }\end{array}$ \\
\hline
\end{tabular}


All data was retrieved from 2012 to 2016 to identify the recent trends of DMAT uses in the oil and gas industry. The keyword deployed for searching the academic publications were "3D model oil gas". The data was filtered through the elimination process. The academic publications and vendor case studies were selected if they sufficiently discussed the DMAT purpose. Figure 3 shows the numbers and years of academic publications and DMAT vendor case studies adopted in this study.

Figure 3: Years and numbers of DMAT Academic Publications and Vendor Case Studies

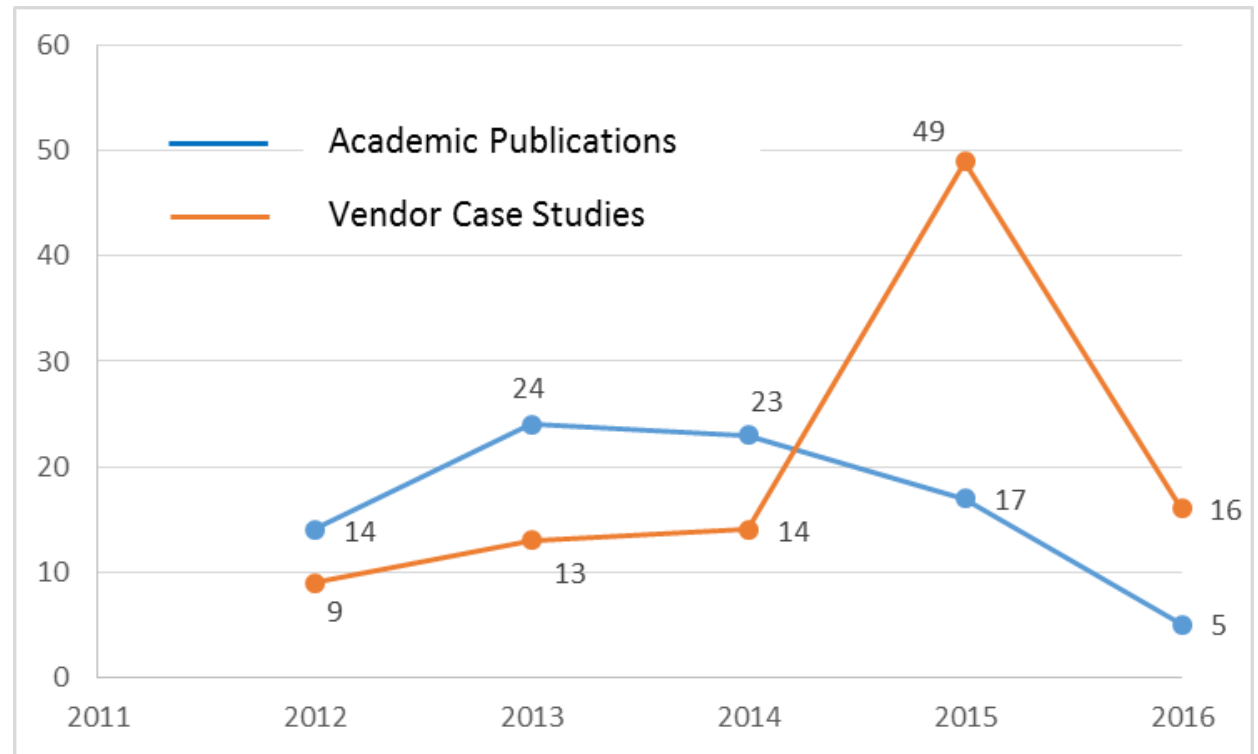

There were total eighty-three (83) DMAT academic publications and one hundred and one (101) DMAT vendor case studies selected in the study. Both types of sources projected a very dissimilar trend. Most of the DMAT academic publications that used in the study were in the year 2013 and 2014 which accounted for 24 and 23 respectively whereas the majority of the DMAT vendor case studies adopted in the study was in the year of 2015, which recorded forty-nine (49) number. 
The data gained from the BIM guidelines, academic publications and vendor case studies were tabulated for analysis. To synthesise the BIM and DMAT uses, the term adopted in the references which had a similar connotation and similar definition were classified into the same theme. The BIM and DMAT uses extracted from the BIM guidelines, DMAT academic publications and DMAT vendor case studies were presented based on the project lifecycle as outlined in Table 4 to ease the understanding of the readers. The data of BIM and DMAT uses were also presented according to the purpose as outlined in Table 1.

Table 4 Project Lifecycle Used In the Study

\begin{tabular}{|c|c|c|c|c|c|c|}
\hline No. & Darko (2014) & $\begin{array}{l}\text { Activity model } \\
\text { of the process } \\
\text { plant life-cycle } \\
\text { (ISO 15926) }\end{array}$ & $\begin{array}{l}\text { Oil and Gas } \\
\text { Industry Life } \\
\text { Cycle } \\
\text { Tabulate in } \\
\text { This Study } \\
\text { (DMAT) }\end{array}$ & Description & $\begin{array}{l}\text { Project } \\
\text { Life } \\
\text { Cycle } \\
\text { Tabulate } \\
\text { in This } \\
\text { Study } \\
\text { (BIM) }\end{array}$ & Description \\
\hline & \multicolumn{2}{|c|}{$\begin{array}{l}\text { The oil and gas industry life } \\
\text { cycle stated in this study are } \\
\text { referred to the phases described } \\
\text { in the above two references. }\end{array}$} & & & & \\
\hline 1 & Exploration & - & Exploration & $\begin{array}{l}\text { It includes seismic } \\
\text { surveys to look for } \\
\text { potential oil or/and gas } \\
\text { sources (Darko 2014). }\end{array}$ & - & - \\
\hline 2 & Appraisal & $\begin{array}{l}\text { Conceptual } \\
\text { Process Design, } \\
\text { Conceptual } \\
\text { Engineering } \\
\text { Design (Front } \\
\text { End) }\end{array}$ & Appraisal & $\begin{array}{l}\text { This phase determines } \\
\text { the projects should } \\
\text { proceed or terminate } \\
\text { based on the results of } \\
\text { the potential of oil } \\
\text { or/and gas reserves } \\
\text { (Darko 2014). It also } \\
\text { involves feasibility } \\
\text { study, site planning } \\
\text { and front-end } \\
\text { engineering design } \\
\text { (FEED) for } \\
\text { production, } \\
\text { transportation and } \\
\text { processing oil and gas } \\
\text { facilities projects. }\end{array}$ & Plan & $\begin{array}{l}\text { This phase is the } \\
\text { most important } \\
\text { phase to determine } \\
\text { the feasibility of } \\
\text { the project. It } \\
\text { includes site } \\
\text { analysis, } \\
\text { determination of } \\
\text { the project } \\
\text { location, } \\
\text { conceptual design } \\
\text { and preparation of } \\
\text { initial estimate. }\end{array}$ \\
\hline 3 & Development & - & Development & $\begin{array}{l}\text { Wells and reservoirs } \\
\text { are } \\
\text { Production } \\
\text { operation }\end{array}$ & - & \\
\hline
\end{tabular}




\begin{tabular}{|c|c|c|c|c|c|c|}
\hline & & & & $\begin{array}{l}\text { and maintenance } \\
\text { strategies are also } \\
\text { established } \quad \text { (Darko } \\
\text { 2014). }\end{array}$ & & \\
\hline $3 a$ & - & $\begin{array}{l}\text { Detailed } \\
\text { Process Design, } \\
\text { Detailed } \\
\text { Engineering } \\
\text { Design }\end{array}$ & Design & $\begin{array}{l}\text { It includes detailed } \\
\text { engineering design. }\end{array}$ & Design & $\begin{array}{l}\text { This phase } \\
\text { includes the } \\
\text { schematic design } \\
\text { of a facility to the } \\
\text { selection of } \\
\text { contractor (Chong, } \\
\text { 2016a). }\end{array}$ \\
\hline $3 b$ & - & $\begin{array}{l}\text { Procure and } \\
\text { Control } \\
\text { Equipment, } \\
\text { Material and } \\
\text { Services, } \\
\text { Suppliers and } \\
\text { Fabricators }\end{array}$ & Procure & $\begin{array}{l}\text { It describes the } \\
\text { ordering, purchasing } \\
\text { and control of } \\
\text { materials, equipment } \\
\text { and services from } \\
\text { fabricators and } \\
\text { suppliers. }\end{array}$ & Procure & $\begin{array}{l}\text { Same as the } \\
\text { description of the } \\
\text { oil and gas } \\
\text { industry } \\
\text { procurement } \\
\text { stage. }\end{array}$ \\
\hline $3 c$ & - & $\begin{array}{l}\text { Construct Plant, } \\
\text { Pre- } \\
\text { Commission }\end{array}$ & Construct & $\begin{array}{l}\text { This stage involves } \\
\text { construction and } \\
\text { fabrication of oil and } \\
\text { gas facilities. }\end{array}$ & Construct & $\begin{array}{l}\text { Same as the } \\
\text { description of the } \\
\text { oil and gas } \\
\text { industry } \\
\text { construction stage. }\end{array}$ \\
\hline 4 & $\begin{array}{l}\text { Production } \\
\text { and Operation }\end{array}$ & $\begin{array}{l}\text { Commission } \\
\text { Plant, Operate } \\
\text { Plant, Maintain } \\
\text { Plant and } \\
\text { Equipment }\end{array}$ & $\begin{array}{l}\text { Production, } \\
\text { Operate and } \\
\text { Maintain }\end{array}$ & $\begin{array}{l}\text { Oil or/and gas reserves } \\
\text { are being extracted and } \\
\text { transported for } \\
\text { processing/ exported. } \\
\text { It also involves } \\
\text { commission, operates, } \\
\text { modifications and } \\
\text { maintains plant and } \\
\text { equipment during the } \\
\text { life of oil and gas } \\
\text { facilities. }\end{array}$ & $\begin{array}{l}\text { Operate } \\
\text { and } \\
\text { Maintain }\end{array}$ & $\begin{array}{l}\text { This stage } \\
\text { includes the } \\
\text { operation and } \\
\text { maintenance of a } \\
\text { facility (Chong } \\
\text { and Wang, 2016). }\end{array}$ \\
\hline 5 & Abandonment & $\begin{array}{l}\text { Decommission, } \\
\text { Demolition } \\
\text { Plant and } \\
\text { Restore Site }\end{array}$ & Demolition & $\begin{array}{l}\text { This phase involves } \\
\text { well abandonment, } \\
\text { dismantle the plants } \\
\text { and restore the site to } \\
\text { its original condition. }\end{array}$ & - & $\begin{array}{l}\text { This section is not } \\
\text { available as none } \\
\text { of this phase } \\
\text { mentioned in the } \\
\text { BIM guidelines. }\end{array}$ \\
\hline
\end{tabular}

Thereafter, a streamlining process was conducted. If a BIM and DMAT use share the common function, they would be aligned with the same theme which represents its use. For the DMAT uses which did not have common functions as the BIM uses, it would be classified as the distinguished DMAT uses. Throughout the streamlining process, the BIM uses which were not commonly applied in the oil 
and gas projects could also be identified. The results were discussed. Limitations, conclusions and recommendations were then formulated and concluded at the end of this review.

\section{Findings}

\subsection{BIM Uses}

Table 5 demonstrates thirty-eight (38) BIM uses which were extracted from twentyeight (28) BIM guidelines. 
Table 5 List of BIM Uses

\begin{tabular}{|c|c|c|c|c|c|c|c|c|}
\hline \multirow[t]{2}{*}{ No. } & \multirow[t]{2}{*}{ BIM Uses/ Description } & \multicolumn{5}{|c|}{ Project Phases } & \multirow[t]{2}{*}{ References (BIM Guidelines) } & \multirow{2}{*}{$\begin{array}{ll}\text { BIM } & \text { Use } \\
\text { Purposes } & \end{array}$} \\
\hline & & 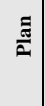 & 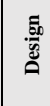 & 妾 & 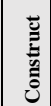 & 总 & & \\
\hline 1 & $\begin{array}{l}\text { Existing Conditions Modeling } \\
\text { A process in which a } 3 D \text { model of the existing conditions for a site, facilities on a site or a specific area within a facility is developed } \\
\text { (PSU, 2011). It includes modelling of the existing ground surface of the structures, the adjacent area and the infrastructure for project } \\
\text { master planning, existing facilities and assets, existing spaces, building components and equipment, geotechnical elements and horizontal } \\
\text { construction such as roadways, raised bridges, walkways and transportation is developed so that the total environment of the facilities } \\
\text { can be modeled effectively (MPA, 2015). }\end{array}$ & $\mathrm{x}$ & $\mathrm{x}$ & & $\mathrm{x}$ & $\mathrm{x}$ & $\begin{array}{l}\text { (BCA, 2013); (COD, 2011); (COSA, 2011): (CRC, 2009): (DOA/DSF, 2012); (FMS, } \\
\text { 2012); (GISFIC, 2013); (GTFM, 2013); (Harvard, 2016); (HKCIC, 2015); (IU, 2015); } \\
\text { (LACCD, 2016); (MPA, 2015); (NATSPEC, 2016); (NHBA, 2012); (NRC, 2014); } \\
\text { (NYCSCA, 2014); (NYDDC, 2012); (OFCC, 2012); (PSU, 2011); (SDCCD, 2012); } \\
\text { (Statsbygg, 2013); (TPA, 2016); (USACE, 2012) }\end{array}$ & Gather; Generate \\
\hline 2. & $\begin{array}{l}\text { Site Analysis } \\
\text { A process in which BIM or GIS tools are used to evaluate the site location to determine :(1) an appropriate location for a future project } \\
(N Y C D D C, 2012) ; \text { and (2) analyse the volumes, location (placement, orientation) of the facility(s) on site (Statsbygg, 2013). }\end{array}$ & $\mathrm{x}$ & & & & & $\begin{array}{l}\text { (BCA, 2013); (COD, 2011);(HKCIC, 2015); (NATSPEC, 2016); (NRC, 2014); } \\
\text { (NYDDC, 2012); (OFCC, 2012); (PSU, 2011); (TPA, 2016); (USACE, 2012) }\end{array}$ & Analyse \\
\hline 3 & $\begin{array}{l}\text { Cost Estimation } \\
\text { A process in which BIM can be used to establish accurate cost estimate and cost effects of changes made to the design can be traced from } \\
\text { the BIM which enables designers to curb excessive cost overruns due to project modifications (NYCDDC, 2012). It includes cost planning, } \\
\text { quantity take-off and cost tracking. }\end{array}$ & $\mathrm{x}$ & \begin{tabular}{|c|}
$x$ \\
\end{tabular} & $\mathrm{x}$ & $\mathrm{x}$ & $\mathrm{x}$ & $\begin{array}{l}\text { (AGC, 2009); (BCA, 2013); (CFM, 2010); (COD, 2011); (COSA, 2011): (CRC, 2009): } \\
\text { (DOA/DSF, 2012); (HKCIC, 2015); (IU, 2015); (LACCD, 2016); (MPA, 2015); } \\
\text { (NATSPEC, 2016); (NRC, 2014); (NYSCA, 2014); (NYDDC, 2012); (PSU, 2011); } \\
\text { (SDCCD, 2012); (SEC, 2013); (TPA, 2016); (USACE, 2012); (GTFM, 2016) }\end{array}$ & $\begin{array}{l}\text { Gather; Generate, } \\
\text { Analyse }\end{array}$ \\
\hline $\mathrm{a}$ & $\begin{array}{l}\text { Cost analysis (5D)/Cost and Schedule Forecast } \\
\text { A process in which a SD BIM is deployed to link the cost data to } 4 D \text { BIM (NATSPEC, 2016) for cost analysis and generating cash flow } \\
\text { forecast report. }\end{array}$ & $\mathrm{x}$ & $\mathrm{x}$ & $\mathrm{x}$ & $\mathrm{x}$ & $\mathrm{x}$ & $\begin{array}{l}\text { (AGC, 2009); (CFM, 2010); (CRC, 2009); (LACCD, 2016); (NATSPEC, 2016); } \\
\text { (NRC, 2014); (SEC, 2013); (Statsbygg, 2013); (TPA, 2016); (USACE, 2012) }\end{array}$ & $\begin{array}{l}\text { Analyse, } \\
\text { Communicate }\end{array}$ \\
\hline 4 & $\begin{array}{l}\text { Phase Planning (4D Modeling)/ Scheduling } \\
\text { A process in which phased occupancy is planned effectively through utilisation of } 4 D \text { model so that a project team can visualise and } \\
\text { communicate for a better understanding of project milestones and construction plans (PSU, 2011). It involves early project phasing to } \\
\text { allow for comparison of different strategies, detail phasing to sequence multi-trade installation and scheduling for project control } \\
\text { (Harvard, 2016). }\end{array}$ & $\mathrm{x}$ & \begin{tabular}{|c|}
$x$ \\
\end{tabular} & $\mathrm{x}$ & $\mathrm{x}$ & & $\begin{array}{l}\text { (AGC, 2009); (BCA, 2013); (CFM, 2010); (COD, 2011); (COSA, 2011); (CRC, 2009); } \\
\text { (DOA/DSF, 2012); (GISFIC, 2013); (GTFM, 2016); (Harvard, 2016); (HKCIC, 2015); } \\
\text { (LACCD, 2016); (MPA, 2015); (NATSPEC, 2016); (NRC, 2014); (NYCSCA, 2014); } \\
\text { (NYDDC, 2012); (PSU, 2011); (SDCCD, 2012); (SEC, 2013); (Statsbygg, 2013); } \\
\text { (TPA, 2016); (USACE, 2012) }\end{array}$ & Communicate \\
\hline 5 & $\begin{array}{l}\text { Programming/ Are and Space Program Validation } \\
\text { A process in which area and program information is extracted from BIM to assess the space design as the design develops. It allows } \\
\text { tracking rentable area, gross area and usable area (Harvard, 2016.). }\end{array}$ & $\mathrm{x}$ & & & & & $\begin{array}{l}\text { (BCA, 2013); (CFM, 2010); (COD, 2011); (COSA, 2011); (CRC, 2009); (DOA/DSF, } \\
\text { 2012); (FMS, 2012); (GISFIC, 2013); (GTFM, 2016); (Harvard, 2016); (HKCIC, 2015); } \\
\text { (IU, 2015); (LACCD, 2016); (MPA, 2015); (NATSPEC, 2016); (NYCSCA, 2014); } \\
\text { (NYDDC, 2012); (OFCC, 2012); (PSU, 2011); (SDCCD, 2012); (Statsbygg, 2013); } \\
\text { (TPA, 2016); (UCASE, 2012) }\end{array}$ & Generate \\
\hline 6 & $\begin{array}{l}\text { Design Authoring } \\
\text { A process in which authoring tools are deployed by multi-disciplinary teams to add richness of information to a facility (HKCIC, 2015). }\end{array}$ & $\mathrm{x}$ & $\mathrm{x}$ & $\mathrm{x}$ & $\mathrm{x}$ & & $\begin{array}{l}\text { (CFM, 2010); (COD, 2011); (COSA, 2011); (FMS, 2012); (Harvard, 2016); (HKCIC, } \\
\text { 2015); (LACCD, 2016); (NRC, 2014); (NYDDC, 2012); (PSU, 2011); (SDCCD, 2012); } \\
\text { (Statsbygg, 2013); (TPA, 2016); (USACE, 2012) }\end{array}$ & Generate \\
\hline 7 & $\begin{array}{l}\text { Design Reviews and Constructability Reviews } \\
\text { A process in which a 3D model is viewed by stakeholders through different forms of presentations to provide their feedbacks for multiple } \\
\text { design aspects validation (PSU, 2011.). It involves design selection from various options provided by the BIM, design communication } \\
\text { through visualisation and digital mock-ups (Harvard, 2016). }\end{array}$ & $\mathrm{x}$ & $\mathrm{x}$ & & & & $\begin{array}{l}\text { (AECUK, 2015); (AGC, 2009); (BCA, 2013); (CFM, 2010); (COD, 2011); (COSA, } \\
\text { 2011); (DOA/DSF, 2011); (FMS, 2012); (GISFIC, 2013); (Harvard, 2016); (HKCIC, } \\
\text { 2015); (LACCD, 2016); (MPA, 2015); (NATSPEC, 2016); (NRC, 2014); (NYCSCA, }\end{array}$ & Communicate \\
\hline
\end{tabular}




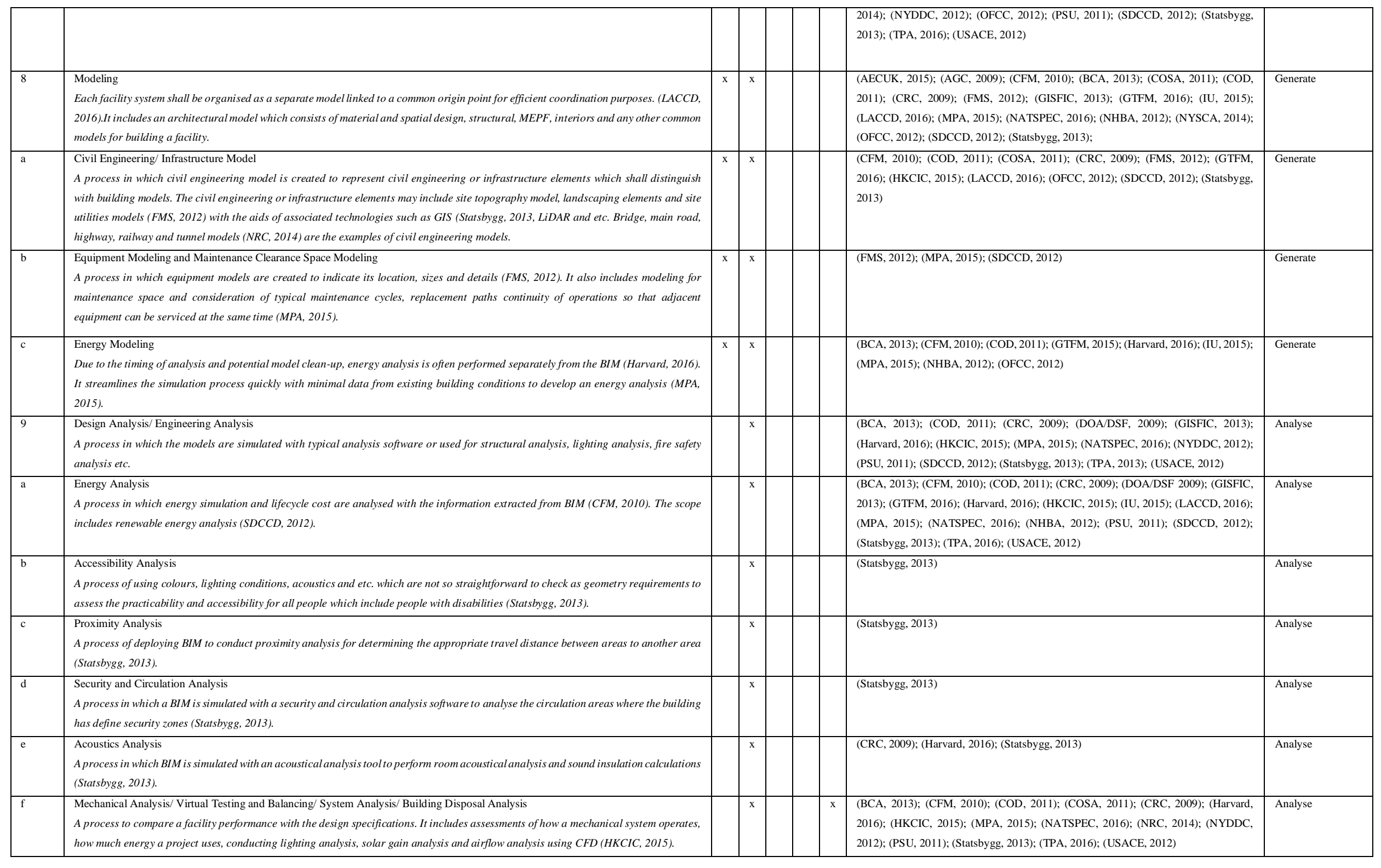




\begin{tabular}{|c|c|c|c|c|c|c|c|c|}
\hline $\mathrm{g}$ & $\begin{array}{l}\text { Sustainability Evaluation/Environmental Analysis/ Environmental Hazardous Products Analysis } \\
\text { A process in which models are used to simulate and validate facility properties such as thermal performance, energy use, structural } \\
\text { calculations, acoustics, heat flows, Life Cycle Costing (LCC), Life Cycle Analysis (LCA) and environmental sustainability (CRC, 2009) } \\
\text { based on the requirement of standard sustainability assessment. }\end{array}$ & $\mathrm{x}$ & $\mathrm{x}$ & $\mathrm{x}$ & $\mathrm{x}$ & $\mathrm{x}$ & $\begin{array}{l}\text { (BCA, 2013); (COD, 2011); (CRC, 2009); (DOA/DSF, 2012); (GISFIC, 2013); } \\
\text { (GTFM, 2016); (Harvard, 2016); (HKCIC, 2015); (LACCD, 2016); (NATSPEC, 2016); } \\
\text { (NYDDC, 2012); (PSU, 2011); (Statsygg, 2013); (TPA, 2016); (USACE, 2012) }\end{array}$ & Analyse \\
\hline $\mathrm{h}$ & $\begin{array}{l}\text { Civil Engineering Analysis } \\
\text { A process in which the models of civil engineering elements can be analysed with the aids GPS, LiDAR and any other forms oftechnologies } \\
\text { such as for the hydraulic design of water supply, sewerage, storm water drainage systems (HKCIC, 2015), surface analysis and traffic } \\
\text { simulation (NRC, 2014). }\end{array}$ & & $\mathrm{x}$ & & & & $\begin{array}{l}\text { (CFM, 2010); (COD, 2011); (HKCIC, 2015); (LACCD, 2016); (SDCCD, 2012); (NRC, } \\
\text { 2014) }\end{array}$ & Analyse \\
\hline $\mathrm{i}$ & $\begin{array}{l}\text { Signal Sighting } \\
\text { A process in which BIM can be deployed to design and test the new signaling proposals before fixing (NRC, 2014). }\end{array}$ & & $\mathrm{x}$ & & & & (NRC, 2014) & Analyse \\
\hline $\mathrm{j}$ & $\begin{array}{l}\text { Code Validation/ Building Code Analysis/Model Checking Program/Compliance Checking/ Design Validation } \\
\text { A process in which code validation soffware is utilised to check the model parameters against project specific codes (PSU, 2011). Apart } \\
\text { from compliance validation, it includes prescription and functionality validation (NRC, 2014). }\end{array}$ & & $\mathrm{x}$ & & & & $\begin{array}{l}\text { (AECUK, 2015); (CFM, 200); (COD, 2011); (CRC, 2009); (GTFM, 2016); (Harvard, } \\
\text { 2016); (IU, 2015); (LACCD, 2016); (MPA, 2015); (NATSPEC, 2016); (NRC, 2014); } \\
\text { (NYDDC, 2012); (OFCC, 2012); (PSU, 2011); (Statsbygg, 2013); (TPA, 2016); } \\
\text { (USACE, 2012) }\end{array}$ & Analyse \\
\hline 10 & $\begin{array}{l}\text { Design Coordination /3D Coordination/Interference Management/Clash Avoidance and Detection } \\
\text { A process in which clash detection soffware is deployed to analyse the BIM for physical interferences between building systems and } \\
\text { components, clashes are manually sorted and reported (Harvard, 2016). Automated clash detection analysis for drainage and utility } \\
\text { networks is made possible with BIM tools (NRC, 2014). }\end{array}$ & & $\mathrm{x}$ & & & & $\begin{array}{l}\text { (ARC, 2009); (BCA, 2013); (CFM, 2010); (COD, 2011); (COSA, 2011); (CRC, 2009); } \\
\text { (DOA/DSF, 2012); (FMS, 2012); (GISFIC, 2013);(GTFM, 2016); (Harvard, 2016); } \\
\text { (HKCIC, 2015); (IU, 2016); (LACCD, 2016); (MPA, 2015); NATSPEC, 2016); (NRC, } \\
\text { 2014); (NYCSA, 2014); (NYDDC, 2012); (OFCC, 2012); (PSU, 2011); (SDCCD, } \\
\text { 2012); (SEC, 2013); (Statsbygg, 2013); (TPA, 2016); (USACE, 2012) }\end{array}$ & Analyse \\
\hline 11 & $\begin{array}{l}\text { Design Documents/ Drawing Generation } \\
\text { A process in which design documents such as schematic, design development, construction and shop drawings are extracted directly from } \\
\text { the BIM repositories or object libraries (PSU, 2011). }\end{array}$ & & $\mathrm{x}$ & & & & $\begin{array}{l}\text { (BCA, 2013); (CFM, 2010); (COD, 2011); (CRC, 2009); (Harvard, 2016); (LACCD, } \\
\text { 2016); (PSU, 2011); (SDCCD, 2012) }\end{array}$ & Communicate \\
\hline 12 & $\begin{array}{l}\text { Digital Fabrication } \\
\text { A process in which geometry from the BIM is extracted for shop drawings and can be sent to computer numerical control equipment for } \\
\text { prefabrication and erected efficiently on site (Harvard, 2016). }\end{array}$ & & & $\mathrm{x}$ & $\mathrm{x}$ & & $\begin{array}{l}\text { (AGC, 2009); (BCA, 2013); (CFM, 200); (COD, 2011); (CRC, 2009); (GTFM, 2016); } \\
\text { (Harvard, 2016); (HKCIC, 2015); (LACCD, 2016); (MPA, 2015); (NATSPEC, 2016); } \\
\text { (NRC, 2014); (NYCSCA, 2014); (NYDDC, 2012); (OFCC, 2012); (PSU, 2011); (TPA, } \\
\text { 2016); (USACE, 2012) }\end{array}$ & Realise \\
\hline 13 & $\begin{array}{l}\text { Subcontractor/ Trade Coordination } \\
\text { A process in which a coordinated model is deployed for the contractor to coordinate with the subcontractors for review the design, optimise } \\
\text { scheduling and field installation prior to installation (NATSPEC, 2016). }\end{array}$ & & & $\mathrm{x}$ & $\mathrm{x}$ & & (AGC, 2009); (CFM, 2010); (COD, 2011); (NATSPEC, 2016); NYCSCA, 2014) & Realise \\
\hline 14 & $\begin{array}{l}\text { Material Management } \\
\text { A process in BIM is used to support multiple-user access, receive, track and control all project deliverables such as prefabrication } \\
\text { components and other small construction support materials to ensure the materials deliver on schedule and meet the quality expectations } \\
(N R C, 2014) .\end{array}$ & & & $\mathrm{x}$ & $\mathrm{x}$ & & (NRC, 2014) & Gather; Generate \\
\hline 15 & $\begin{array}{l}\text { Equipment Management } \\
\text { A process in which BIM is deployed to support construction equipment management such as scheduling the downtime to fit project } \\
\text { workload, produce maintenance schedules, complete service history and work arrangement }(N R C, 2014) \text {. }\end{array}$ & & & $\mathrm{x}$ & $\mathrm{x}$ & & (NRC, 2014) & Gather; Generate \\
\hline 16 & $\begin{array}{l}\text { Site Utilisation Planning/ Site and Logistic Planning } \\
\text { A process in which detailed logistic objects are modeled in the BIM (Harvard, 2016) and link to construction schedule (4D) (HKCIC, } \\
\text { 2015) for permanent and temporary facilities on site (PSU, 2011). }\end{array}$ & & & & $\mathrm{x}$ & & $\begin{array}{l}\text { (AGC, 2009); (COD, 2011); (CRC, 2009); (Harvard, 2016); (HKCIC, 2015); } \\
\text { (NATSPEC, 2016); (NRC, 2014); (PSU, 2011); (TPA, 2016); (USACE, 2012) }\end{array}$ & Communicate \\
\hline 17 & $\begin{array}{l}\text { 3D Control and Planning (Digital Layout)/In field Construction Layout } \\
\text { A process in which layout points are taken from the BIM and loaded into robotic total stations for layout. Conversely, layout points are } \\
\text { captured in the field during construction and round-tripped back to the model for proactive quality control (MPA, 2015). }\end{array}$ & & & & $\mathrm{x}$ & & $\begin{array}{l}\text { (COD, 2011)); (Harvard, 2016); (HKCIC, 2015); (MPA, 2015); (NRC, 2014); (PSU, } \\
\text { 2011); (USACE, 2012) }\end{array}$ & Communicate \\
\hline
\end{tabular}




\begin{tabular}{|c|c|c|c|c|c|c|c|c|}
\hline 18 & $\begin{array}{l}\text { Lift Planning } \\
\text { A process in which lift plan models are created through collaboration between the structure engineers and experienced site personnel } \\
\text { such as lift supervisor to communicate the lift plan for execution (NATSPEC, 2016). }\end{array}$ & & & & $\mathrm{x}$ & & (NATSPEC, 2016) & Communicate \\
\hline 19 & $\begin{array}{l}\text { Safety/ Safety Planning/Site Safety Review } \\
\text { A process in which BIM is deployed to develop safety plans for communication on site and off site such as information for emergency } \\
\text { routes of public safety measures can be extracted from the BIM (Harvard, 2016) and BIM-based orientation can be used to provide safety } \\
\text { training (MPA, 2015). }\end{array}$ & & & & $\mathrm{x}$ & & 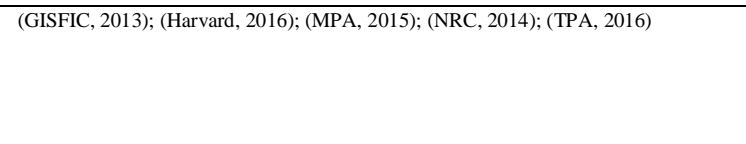 & Communicate \\
\hline 20 & $\begin{array}{l}\text { Construction System Design } \\
\text { A process in which complex building systems such as modular construction components, formwork and scaffolding can be modeled to } \\
\text { improve planning, construction productivity and safety (NATSPEC, 2016). }\end{array}$ & & & & $\mathrm{x}$ & & $\begin{array}{l}\text { (COD, 2011); (NATSPEC, 2016); (NYDDC, 2012); (PSU, 2011); (TPA, 2016); } \\
\text { (USACE, 2012) }\end{array}$ & $\begin{array}{l}\text { Generate; } \\
\text { Communicate }\end{array}$ \\
\hline 21 & $\begin{array}{l}\text { Progress Tracking } \\
\text { A process in which } 4 D \text { BIM is integrated with laser scanning and mobile computing to assist project managers in assessing construction } \\
\text { progress effectively and make a timely decision if schedule delay appeared. }\end{array}$ & & & & $\mathrm{x}$ & & (NRC, 2014) & Gather \\
\hline 22 & $\begin{array}{l}\text { Field and Management Tracking/ Quality Tracking and Reporting } \\
\text { A process in which Field Management soffware is used during the construction, commissioning, and handover process to manage, track, } \\
\text { task, and report on quality, safety, documents to the field, commissioning, and handover programs, connected to BIM for project } \\
\text { compliance (PSU,n.d.). }\end{array}$ & & & & $\mathrm{x}$ & & (PSU, 2011); (Statsbygg, 2013); (USACE, 2012); (NRC, 2014) & $\begin{array}{l}\text { Gather; Generate; } \\
\text { Communicate }\end{array}$ \\
\hline 23 & $\begin{array}{l}\text { Field Supplements } \\
\text { Data extracted from BIM can be used to support field supplements (Harvard, 2016) such as construction drawings and schedules, as-built } \\
\text { documents and sustainability certification documentation to be submitted as part of the project deliverables. }\end{array}$ & & & & $\mathrm{x}$ & & $\begin{array}{l}\text { (AGC, 2009); (Harvard, 2016); (LACCD, 2016); (MPA, 2015); (SDCCD, 2012); } \\
\text { (Statsbygg, 2013); (TPA, 2016) }\end{array}$ & Communicate \\
\hline 24 & $\begin{array}{l}\text { Record Model/ As-built Model } \\
\text { Record Modeling is the process used to depict an accurate representation of the physical conditions, environment, and assets of a facility. } \\
\text { It is the culmination of all the BIM Modeling throughout the project, including linking Operation, Maintenance, and Asset data to the As- } \\
\text { Built model (created from the Design, Construction, } 4 \text { C Coordination Models, and Subcontractor Fabrication Models) to deliver a record } \\
\text { model to the owner or facility manager (PSU,2011). }\end{array}$ & & & & $\mathrm{x}$ & & $\begin{array}{l}\text { (AECUK, 2015); (AGC, 2009); (BCA, 2013); (COD, 2011); (COSA 2011); (CRC, } \\
\text { 2009); (GTFM, 2016); (Harvard, 2016); (HKCIC, 2015); (IU, 2015); (LACCD, 2016); } \\
\text { (MPA, 2015); (NATSPEC, 2016); (NRC, 2014); (NYDDC, 2012); (OFCC, 2012); } \\
\text { (PSU, 2011); (SDCCD, 2012); (Statsbygg, 2013); (TPA, 2016); (USACE, 2012) }\end{array}$ & Generate \\
\hline 25 & $\begin{array}{l}\text { COBie/ Commissioning } \\
\text { A systematic process of verifying that all building systems perform interactively according to the design intent and the owner's operational } \\
\text { needs (MPA, 2015). }\end{array}$ & $\mathrm{x}$ & $\mathrm{x}$ & $\mathrm{x}$ & $\mathrm{x}$ & $\mathrm{x}$ & $\begin{array}{l}\text { (CFM, 2010); (COD, 2011); (FMS, 2012); (GTFM, 2016); (IU, 2015); (LACCD, 2016); } \\
\text { (MPA, 2015); (NATSPEC, 2016); (NRC, 2014); (SDCCD, 2012); (SEC, 2013); } \\
\text { (Statsbygg, 2013); (TPA, 2016); (USACE, 2012) }\end{array}$ & $\begin{array}{l}\text { Communicate; } \\
\text { Realise }\end{array}$ \\
\hline 26 & $\begin{array}{l}\text { Other FM information handover } \\
\text { A process in which where the client and BIM Team determine that use of the COBie system is not appropriate for the project, other specific } \\
\text { information required for facility management and the strategy for delivering it are purposed (NATSPEC, 2016). }\end{array}$ & & & & & $\mathrm{x}$ & (NATSPEC, 2016) & $\begin{array}{l}\text { Communicate; } \\
\text { Realise }\end{array}$ \\
\hline 27 & $\begin{array}{l}\text { Operation and Maintenance Scheduling/ Preventive Maintenance Analysis } \\
\text { A process of record model/ as-built model is deployed with building management system such as building automation system, computerised } \\
\text { maintenance management system to plan, manage and track operation and maintenance activities (PSU, 2011). }\end{array}$ & & & & & $\mathrm{x}$ & $\begin{array}{l}\text { (BCA, 2013); (COD, 2011); (CRC, 2009); (HKCIC, 2015); (MPA, 2015); (NATSPEC, } \\
\text { 2016); (NRC, 2014); (PSU, 201 1); (SDCCD, 2012); (Statsbygg, 2013); (TPA, 2016); } \\
\text { (USACE, 2012) }\end{array}$ & Communicate \\
\hline 28 & $\begin{array}{l}\text { Asset Management/Facility Management } \\
\text { A process of bi-directionally linking an as-built model database to an organised building management system which can be used to } \\
\text { maintain and operate a facility and its assets (HKCIC,2015).The assets include physical components, systems, surrounding environment } \\
\text { and equipment (NRC, 2014). }\end{array}$ & & & & & $\mathrm{x}$ & $\begin{array}{l}\text { (BCA, 2013); (COD, 2011); (CRC, 2009); (Harvard, 2016); (HKCIC, 2015); (MPA, } \\
\text { 2015); (NATSPEC, 2016); (NRC, 2014); (NYDDC, 2012); (OFCC, 2012); (PSU, } \\
\text { 2011); (SDCCD, 2012); (Statsbygg, 2013); (TPA, 2016); (USACE, 2012) }\end{array}$ & $\begin{array}{l}\text { Gather; Generate; } \\
\text { Communicate }\end{array}$ \\
\hline 29 & $\begin{array}{l}\text { Maintenance Training } \\
\text { BIM can be used during commissioning, preoccupation, and post-occupation to train staff on asset location, maintenance access and } \\
\text { maintenance procedures. This information can be developed into a mobile accessible package (MPA, 2015). }\end{array}$ & & & & & $\mathrm{x}$ & (MPA, 2015) & Realise \\
\hline
\end{tabular}




\begin{tabular}{|c|c|c|c|c|}
\hline 30 & $\begin{array}{l}\text { Space Management and Tracking } \\
\text { A process in which BIM may integrate with spatial tracking soffware to assess, manage and track the existing use space and associated } \\
\text { resources within a project (HKCIC, 2015) }\end{array}$ & $\mathrm{x}$ & $\begin{array}{l}\text { (BCA, 2013); (COD, 2011); (CRC, 2009); Harvard, 2016); (HKCIC, 2016); (MPA, } \\
\text { 2015); (NATSPEC, 2016); (PSU, 2011); (SDCCD, 2012); (TPA, 2016); (USACE, } \\
\text { 2012) }\end{array}$ & $\begin{array}{l}\text { Gather; } \\
\text { Communicate }\end{array}$ \\
\hline 31 & $\begin{array}{l}\text { Disaster Planning/Contingency Planning Analysis } \\
\text { A process in which BIM is used in conjunction with building management system for emergency response planning (NATSPEC, 2016). }\end{array}$ & $\mathrm{x}$ & $\begin{array}{l}\text { (COD, 2011); (CRC, 2009); (Harvard, 2016); (MPA, 2015); (NATSPEC, 2016); (NRC, } \\
\text { 2014); (PSU, 2011); (SDCCD, 2012); (Statsbygg, 2013); (TPA, 2016); (USACE, 2012) }\end{array}$ & $\begin{array}{l}\text { Generate; Analyse; } \\
\text { Communicate }\end{array}$ \\
\hline 32 & $\begin{array}{l}\text { Assessment Models } \\
\text { BIM can be used in the field for efficient data collection. Mobile software supporting BIM shall be considered by the assessment team } \\
\text { (MPA, 2015). }\end{array}$ & $\mathrm{x}$ & (MPA, 2015) & Gather \\
\hline 33 & $\begin{array}{l}\text { Resiliency Modeling } \\
\text { BIM can be used to create resiliency modeling particular for the projects where their assets and properties are located in areas subject } \\
\text { to environmental change (MPA, 2015). }\end{array}$ & $\mathrm{x}$ & (MPA, 2015) & Generate \\
\hline 34 & $\begin{array}{l}\text { Road/Rail Management } \\
\text { A process in which BIM is utilised to provide solutions to build and manage infrastructure models, analyse current working conditions of } \\
\text { infrastructure, plan for infrastructure improvement and future growth with the aids of various forms of technologies such as geospatial } \\
\text { tracking and graphical representation of the networks (NRC, 2014). }\end{array}$ & $\mathrm{x}$ & (NRC, 2014) & Realise \\
\hline 35 & $\begin{array}{l}\text { Transportation/Logistic Management System } \\
\text { A process in which BIM transportation management tools are deployed to support entire transportation lifecycle ranging from creating } \\
\text { the least cost shipment plans and maximising loading capacity to streamlining freight financial administration for match- and auto-pay } \\
\text { or self-invoicing processes, as well as leverage end-to-end visibility for proactive monitoring and intelligent exception management for } \\
\text { whole distribution network (NRC, 2014). }\end{array}$ & $\mathrm{x}$ & (NRC, 2014) & Realise \\
\hline 36 & $\begin{array}{l}\text { Traffic Volume Simulation } \\
\text { A process in which performance measures generated by BIM models and BIM visualization capabilities enable detailed operational } \\
\text { analyses of travel corridors in the area and assist in determining the potential effectiveness of transportation projects and access } \\
\text { management practices (NRC, 2014). }\end{array}$ & $\mathrm{x}$ & (NRC, 2014) & Analyse \\
\hline 37 & $\begin{array}{l}\text { GIS Asset Tracking } \\
\text { A process in which BIM is deployed to monitor location and movement of objects in real time. Objects that can transmit their geographic } \\
\text { location via Global Positioning Systems (GPS) or similar technologies can be dynamically tracked on a display map that can be shared } \\
\text { via the Internet or intranet (NRC, 2014). }\end{array}$ & $\mathrm{x}$ & (NRC, 2014) & Gather \\
\hline 38 & $\begin{array}{l}\text { Water Mitigation and Planning } \\
\text { A process in which BIM operation tools can be deployed to support appropriate legislation for flood plain zoning, implementation and } \\
\text { collection of data essential for the assessment of the community'sflood risk (NRC, 2014). }\end{array}$ & $\mathrm{x}$ & (NRC, 2014) & Communicate \\
\hline
\end{tabular}

\subsection{DMAT Uses in the Oil and Gas Industry}

Table 6 demonstrates thirty-two (32) DMAT uses extracted from a total of eighty-three (83) academic publications and one hundred and one (101) DMAT vendor case studies. 


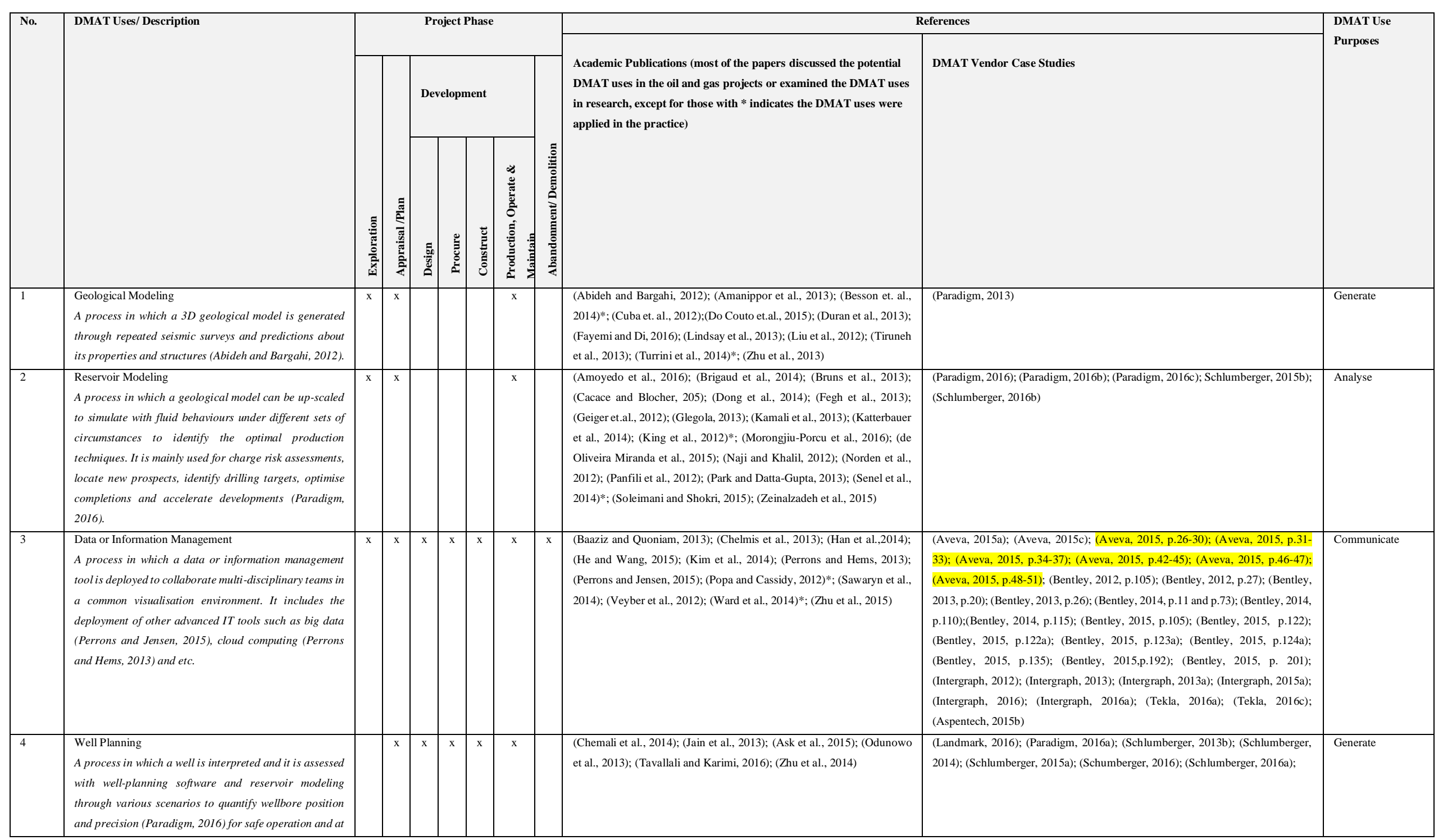




\begin{tabular}{|c|c|c|c|c|c|c|c|c|c|c|c|}
\hline & $\begin{array}{l}\text { the lowest cost. A } 3 D \text { drillable trajectory is designed } \\
\text { inside a subsurface model with well control simulation } \\
\text { soffware to understand and mitigate operational risks and } \\
\text { meet drilling regulations (Schlumberger, 2016). As } \\
\text { drilling operation is progress, reservoir model is updated } \\
\text { and coupled with simulation soffware to situate the good } \\
\text { structure and provide a more realistic drilling (Chemali } \\
\text { et al., 2014). }\end{array}$ & & & & & & & & & & \\
\hline 5 & $\begin{array}{l}\text { Subsurface Model Review } \\
\text { A process in which a } 3 D \text { subsurface model and other } \\
\text { necessary data are reviewed by stakeholders through } \\
\text { different forms of presentations to assist in decision } \\
\text { making for well planning, drilling and production } \\
\text { optimisation (Schlumberger, 2013). }\end{array}$ & $\mathrm{x}$ & $\mathrm{x}$ & $\mathrm{x}$ & & & $\mathrm{x}$ & & - & (Schlumberger, 2013); (Schlumberger, 2014a) & Communication \\
\hline 6 & $\begin{array}{l}\text { Drilling Operation } \\
\text { Drilling operations include utilisation of drilling } \\
\text { operations software and other services for drilling } \\
\text { engineers and the rig site to continuously monitor and } \\
\text { analyse drilling operations for drilling performance } \\
\text { optimisation, wellbore assurance, risk mitigation, and } \\
\text { operational efficiency (Schlumberger, 2016). The result of } \\
\text { the drilling data analysing data grid could be visualised } \\
\text { through 3D model (Zhang and Zhang, 2012). }\end{array}$ & & $\mathrm{x}$ & $\mathrm{x}$ & $\mathrm{x}$ & $\mathrm{x}$ & $\mathrm{x}$ & & $\begin{array}{l}\text { (Downtown, 2015); (Iversen et al., 2013); (Nikolaou, 2013); (Tavallali } \\
\text { and Karimi, 2016);(Zhang and Zhang, 2012) }\end{array}$ & (Schlumberger, 2012); (Schlumberger, 2013a) & Realise \\
\hline 7 & Existing Conditions Modeling & & $\mathrm{x}$ & $\mathrm{x}$ & & $\mathrm{x}$ & $\mathrm{x}$ & $\mathrm{x}$ & (Ward et al., 2014)* & - & Gather, Generate \\
\hline $\mathrm{a}$ & $\begin{array}{l}\text { As-Built Model } \\
\text { A process in which an as-built model of an existing facility } \\
\text { or a new built fabrication model is created through laser } \\
\text { scanning technology (Aveva, 2015, p.16-19). }\end{array}$ & & $\mathrm{x}$ & $\mathrm{x}$ & & $\mathrm{x}$ & $\mathrm{x}$ & $\mathrm{x}$ & - & $\begin{array}{l}\text { (Aveva, 2015a); (Aveva, 2015, p.10-12); (Aveva, 2015, p.13-15); (Aveva, 2015, } \\
\text { p.16-19); (Aveva, 2015, p.26-30); (Aveva, 2015, p.3-5); (Bentley, 2012, p. 109); } \\
\text { (Bentley, 2014, p.98); (Intergraph, 2014a) }\end{array}$ & Gather, Generate \\
\hline 8 & Programming & & $\mathrm{x}$ & & & & & & (Ward et al., 2014)* & - & Generate \\
\hline 9 & Phase Planning (4D Modeling)/ Scheduling & & $\mathrm{x}$ & $\mathrm{x}$ & & $\mathrm{x}$ & $\mathrm{x}$ & $\mathrm{x}$ & (Kim et. al., 2013); (Ward et al., 2014)*; (Zhou et al., 2015a) & $\begin{array}{l}\text { (Aveva, 2015,p.31-33); (Bentley, 2013,p.62); (Bentley, 2015,p.13); (Synchro, } \\
\text { 2014); (Synchro, 2015) }\end{array}$ & Communicate \\
\hline 10 & Cost Estimation & & $\mathrm{x}$ & $\mathrm{x}$ & $\mathrm{x}$ & $\mathrm{x}$ & $\mathrm{x}$ & & - & (Aspentech, 2015); (Asptentech, 2016) & $\begin{array}{l}\text { Gather; Generate; } \\
\text { Analyse }\end{array}$ \\
\hline a & $\begin{array}{l}\text { Quantity Extraction } \\
\text { It is a process in which a } 3 D \text { model is used to extract } \\
\text { quantity for cost estimation (Aveva, 2015, p.13-15). }\end{array}$ & & $\mathrm{x}$ & $\mathrm{x}$ & $\mathrm{x}$ & $\mathrm{x}$ & $\mathrm{x}$ & & (Ward et al., 2014)* & $\begin{array}{l}\text { (Aveva, 2015,p.13-15); (Aveva, 2015,p.26-30); (Aveva, 2015,p.34-37); (Bentley, } \\
\text { 2012, p. 125); (Bentley, 2013,p.143); (Bentley, 2013,p.146); (Bentley, } \\
\text { 2013,p.20); (Bentley,2015,p.103); (Bentley, 2015,p. 122); (Bentley, 2015,p.192); } \\
\text { (Intergraph, 2013); (Intergraph, 2014a); (Intergraph, 2015); (Intergraph, 2015a); } \\
\text { (Intergraph, 2016a); (Tekla, 2016); (Tekla, 2016a) }\end{array}$ & Gather \\
\hline $\mathrm{b}$ & Cost Analysis (5D)/Cost and Schedule Forecast & & $\mathrm{x}$ & $\mathrm{x}$ & $\mathrm{x}$ & $\mathrm{x}$ & $\mathrm{x}$ & & (Wang et al., 2014a) & & Analyse \\
\hline 11 & Design Authoring & & $\mathrm{x}$ & $\mathrm{x}$ & $\mathrm{x}$ & $\mathrm{x}$ & & & (Ward et al., 2014)*; (Xie and Ma, 2015) & $\begin{array}{l}\text { (Autodesk, 2012); (Autodesk, 2012a); (Aveva, 2015, p.48-51); (Bentley, 2012, } \\
\text { p.105); (Bentley, 2012, p.109); (Bentley, 2012, p.27); (Bentley, 2013,p.143); }\end{array}$ & Generate \\
\hline
\end{tabular}




\begin{tabular}{|c|c|c|c|c|c|c|c|c|c|}
\hline & & & & & & & & $\begin{array}{l}\text { (Bentley, 2013, p.143); (Bentley, 2013,p.146); (Bentley, 2014,p.110); (Bentley, } \\
\text { 2014, p.115);(Bentley, 2015, p.103); (Bentley, 2015, p.122); (Bentley, 2015, } \\
\text { p.122a); (Bentley, 2015, p.135); (Bentley, 2015, p.201); (Intergraph, 2013); } \\
\text { (Intergraph, 2013a); (Intergraph, 2014); (Intergraph, 2014a); (Intergraph, 2015a); } \\
\text { (Intergraph, 2016); (Tekla, 2016); (Tekla, 2016a); (Tekla, 2016c) }\end{array}$ & \\
\hline 12 & Design Reviews & $\mathrm{x}$ & $\mathrm{x}$ & & & & $\begin{array}{l}\text { (Carvalho et al., 2012); (Kim et al., 2014); (Muley et al., 2014); (Ward et } \\
\text { al., 2014)* }\end{array}$ & $\begin{array}{l}\text { (Aveva, 2015a); (Aveva, 2015,p.20-22); (Aveva, 2015,p.26-30); (Aveva, } \\
\text { 2012,.27); (Bentley, 2013, p. 20); (Bentley, 2014,p.110); (Bentley, 2014,p.115); } \\
\text { (Bentley, 2015,p. 103); (Bentley, 2015,p.122); (Bentley, 2015,p.124); (Bentley, } \\
\text { 2015,p.124a); (Bentley, 2015,p.135); (Bentley, 2015,p.201); (Intergraph, 2013); } \\
\text { (Intergraph, 2015a); (Intergraph, 2016a); (Tekla, 2016a) }\end{array}$ & Communicate \\
\hline 13 & $\begin{array}{l}\text { Modeling, Instrumentation and Diagram } \\
\text { It includes mechanical, structural, piping, equipment, } \\
\text { electrical, civil engineering and any other engineering } \\
\text { modeling necessary for a facility. Concurrent design of } \\
\text { different disciplines may exist under a collaboration } \\
\text { platform (Intergraph, 2016; Aveva, 2016). It also includes } \\
\text { the process of facilitating the instrumentation and } \\
\text { diagram from various disciplines to support operational } \\
\text { tasks such as generating new as-built data, offer interface } \\
\text { for calibration and SAP (one of the ERP providers) for } \\
\text { maintenance scheduling (Intergraph, 2016).All tools } \\
\text { discussed are necessary to support the changes made to } \\
\text { ensure the information are always up-to-date. }\end{array}$ & $\mathrm{x}$ & $\mathrm{x}$ & $\mathrm{x}$ & $\mathrm{x}$ & $\mathrm{x}$ & $\begin{array}{l}\text { (Liet al., 2013); (Savazzi et al., 2013); (Ward et al,, 2014)*; (Zhou et al., } \\
\text { 2015); (Norton et al., 2013); (Ma, 2014)* }\end{array}$ & 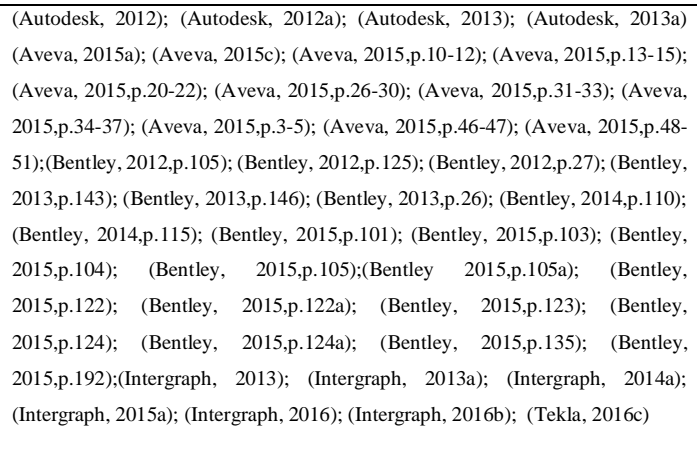 & Generate \\
\hline 14 & Design Analysis/Engineering Analysis & & $\mathrm{x}$ & & & & - & - & Analyse \\
\hline a & $\begin{array}{c}\text { Structural Analysis } \\
\text { s. }\end{array}$ & & $\mathrm{x}$ & & & & (Ward et al., 2014)* & $\begin{array}{l}\text { (Bentley, 2012,p.105); (Bentley, 2014,p.110); (Bentley, 2014,p.95); (Bentley, } \\
\text { 2015,p.101); (Bentley, 2015,p.102); (Bentley, 2015,p. 103); (Tekla, 2016) }\end{array}$ & Analyse \\
\hline $\mathrm{b}$ & $\begin{array}{l}\text { Offshore Structural Analysis } \\
\text { A process in which a structure is simulated with offshore } \\
\text { system response such as hydrostatic, hydrodynamic, } \\
\text { mooring, and structural behaviour, for an example, blast } \\
\text { and explosion analysis to assess the offshore structural } \\
\text { integrity (Bentley, 2016). }\end{array}$ & & & & & & (Munoz-Garcia, 2013); (Paris and Cahay, 2015); (Ma, 2014)* & 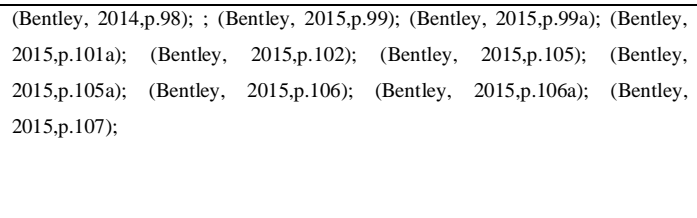 & \\
\hline $\mathrm{c}$ & $\begin{array}{l}\text { Spatial, Raceway and Cable System Analysis } \\
\text { A } 3 \text { model can simulate with raceway and cable system } \\
\text { analysis soffware to identify the best path through } \\
\text { raceways using different segregation criteria and routing } \\
\text { methodsfor plant design (Bentley 2015, p.103). }\end{array}$ & & $\mathrm{x}$ & & & & - & (Aveva, 2015,p.31-33); (Aveva, 2015,p.34-37);(Bentley, 2015,p. 103) & Analyse \\
\hline d & $\begin{array}{l}\text { Process Analysis } \\
\text { A } 3 D \text { model can also be simulated with process analysis } \\
\text { software to address engineering challenges such as the }\end{array}$ & & $\mathrm{x}$ & & & & (Pathak et al., 2013); (Walnum et al., 2013); (Kvesic et al. 2012) & $\begin{array}{l}\text { (Aveva, 2015,p.34-37); (Intergraph, 2014); (Intergraph, 2015a); (Aspentech, } \\
\text { 2015a) }\end{array}$ & Analyse \\
\hline
\end{tabular}




\begin{tabular}{|c|c|c|c|c|c|c|c|c|c|}
\hline & $\begin{array}{l}\text { multiphase flow modeling, gas processing, refining and } \\
\text { LNG process (Aveva 2015, p.34-37). }\end{array}$ & & & & & & & & \\
\hline $\mathrm{e}$ & $\begin{array}{l}\text { Material and/or Pipe Stress Analysis } \\
\text { A process in which material is analysed with simulation } \\
\text { soffware. One of the examples is that the piping analysis } \\
\text { was deployed to analyse the flexibility and stress of pipe. } \\
\text { The model created could clearly indicate areas of concern } \\
\text { via color-coded stress models and animated } \\
\text { displacementsfor any stress load case (Intergraph } 2015 \text {; } \\
\text { Intergraph 2016; Intergraph 2016a). }\end{array}$ & & $\mathrm{x}$ & & & & (Hu et al., 2015); (Munoz-Garcia, 2013) & $\begin{array}{l}\text { (Aveva, 2015, p. 31-33); (Bentley, 2014,p.110);(Bentley, 2015, p.101); (Bentley, } \\
\text { 2015, p. 103); (Bentley, 2015,p.105a); (Bentley, 2015,p.122a); (Bentley, } \\
\text { 2015,p.123); (Bentley, 2015,p.124); (Bentley, 2015,p.135);(Intergraph, 2013); } \\
\text { (Intergraph, 2014); (Intergraph, 2014a); (Intergraph, 2015a) }\end{array}$ & Analyse \\
\hline $\mathrm{f}$ & Acoustic Analysis & & $\mathrm{x}$ & & & & - & (Bentley, 2015,p.123) & Analyse \\
\hline $\mathrm{g}$ & Civil Engineering Analysis & & $\mathrm{x}$ & & & & (Ward et. al., 2014)* & - & \\
\hline $\mathrm{h}$ & $\begin{array}{l}\text { Geospatial Analysis } \\
\text { The analysis is used to design and installation of the } \\
\text { pipeline, field gathering stations, gas distribution } \\
\text { manifolds, flow and trunklines, and water and gas re- } \\
\text { injection facilities in El Merk (Intergraph, 2016b). }\end{array}$ & $\mathrm{x}$ & $\mathrm{x}$ & & & $\mathrm{x}$ & & (Intergraph, 2016b) & Analyse \\
\hline i & $\begin{array}{l}\text { Economic Evaluation } \\
\text { A process in which an economic model is embedded into } \\
\text { process modeling to assess the viability of the capital, } \\
\text { production, operation costs and any other associated } \\
\text { costs arising from the planning until the demolition of the } \\
\text { oil and gas facilities (Berk, 2011)s. }\end{array}$ & $\mathrm{x}$ & $\mathrm{x}$ & $\mathrm{x}$ & $\mathrm{x}$ & $\mathrm{x}$ & - & (Aspentech, 2015); (Asptentech, 2016) & Analyse \\
\hline 15 & $\begin{array}{l}\text { Code Validation/ Building Code Analysis/ Model } \\
\text { Checking Program/Compliance Checking/ Design } \\
\text { Validation }\end{array}$ & & $\mathrm{x}$ & & & & - & $\begin{array}{l}\text { *Almost most of the common design soffware has code compliance checking } \\
\text { feature. }\end{array}$ & Analyse \\
\hline 16 & Design Documents & $\mathrm{x}$ & $\mathrm{x}$ & $\mathrm{x}$ & $\mathrm{x}$ & & (Ward et al., 2014)* & 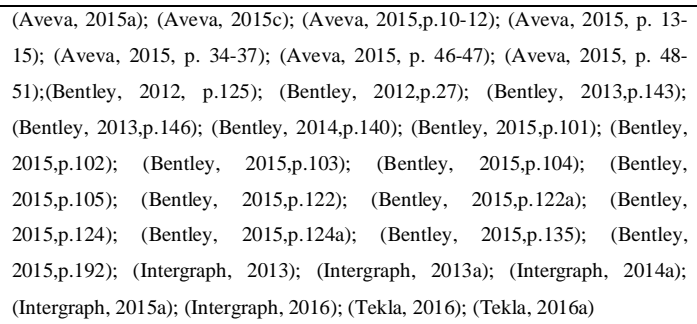 & Communicate \\
\hline 17 & $\begin{array}{l}\text { Design Coordination /3D Coordination/Interference } \\
\text { Management/Clash Avoidance and Detection }\end{array}$ & & $\mathrm{x}$ & $\mathrm{x}$ & $\mathrm{x}$ & & (Ward et al., 2014)* & $\begin{array}{llll}\text { (Aveva, 2015a); } & \text { (Aveva, 2015c); (Aveva, 2015,p.10-12); (Aveva, 2015,p.13-15); } \\
\text { (Aveva, 2015,p.26-30); (Aveva, 2015,p.31-33); (Aveva, 2015,p.34-37); } & \text { (Aveva, } \\
\text { 2015,p.46-47); } & \text { (Aveva, 2015,p.48-51); } & \text { (Bentley, 2012,p.27); } & \text { (Bentley, } \\
\text { 2013,p.143); } & \text { (Bentley, 2014,p.110); } & \text { (Bentley, 2014,p.115); } & \text { (Bentley, } \\
\text { 2015,p.101); } & \text { (Bentley, 2015,p.103); } & \text { (Bentley, 2015,p.105); } & \text { (Bentley, } \\
\text { 2015,p.105a); } & \text { (Bentley, 2015,p.122); } & \text { (Bentley, 2015,p.122a); } & \text { (Bentley, }\end{array}$ & Analyse \\
\hline
\end{tabular}




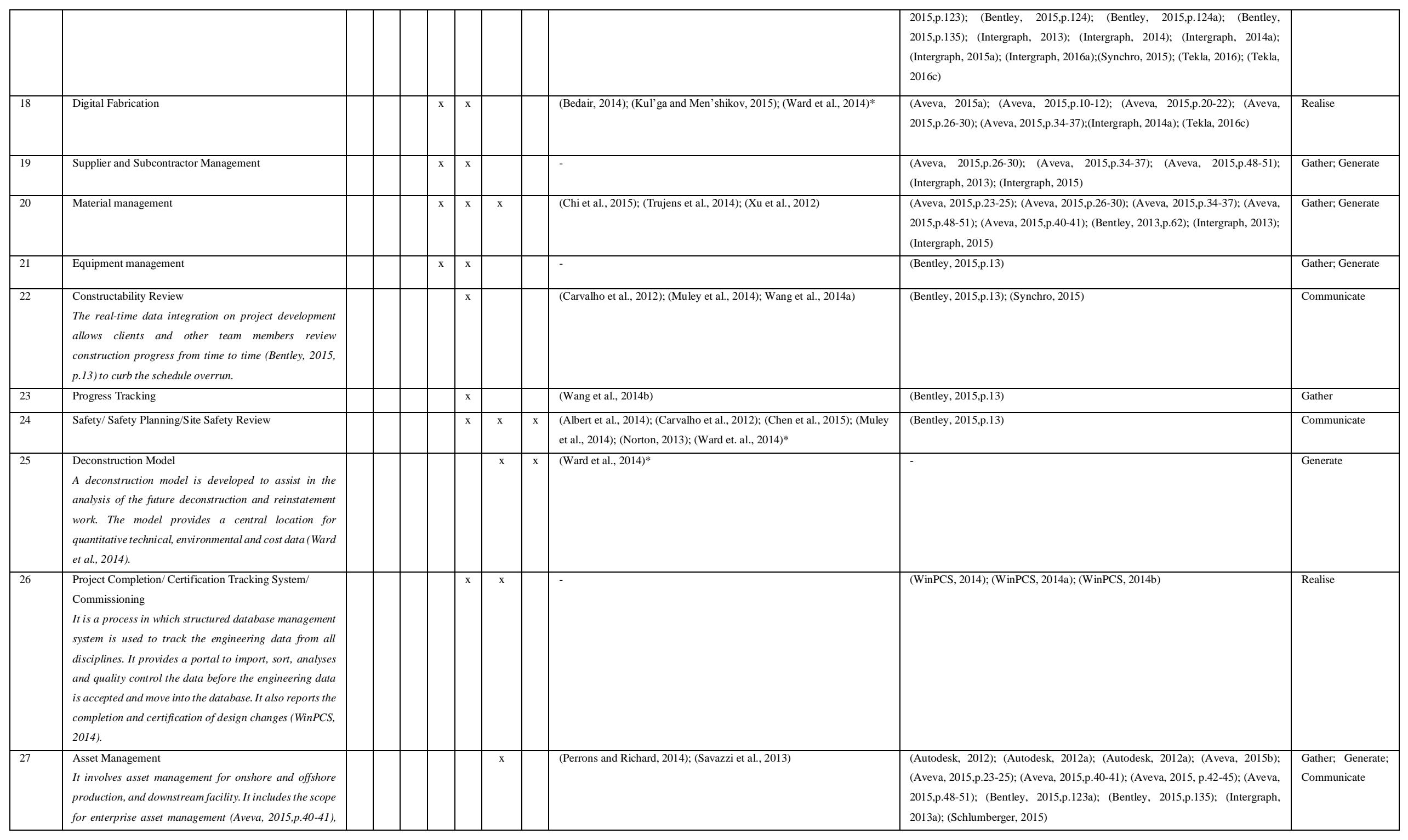




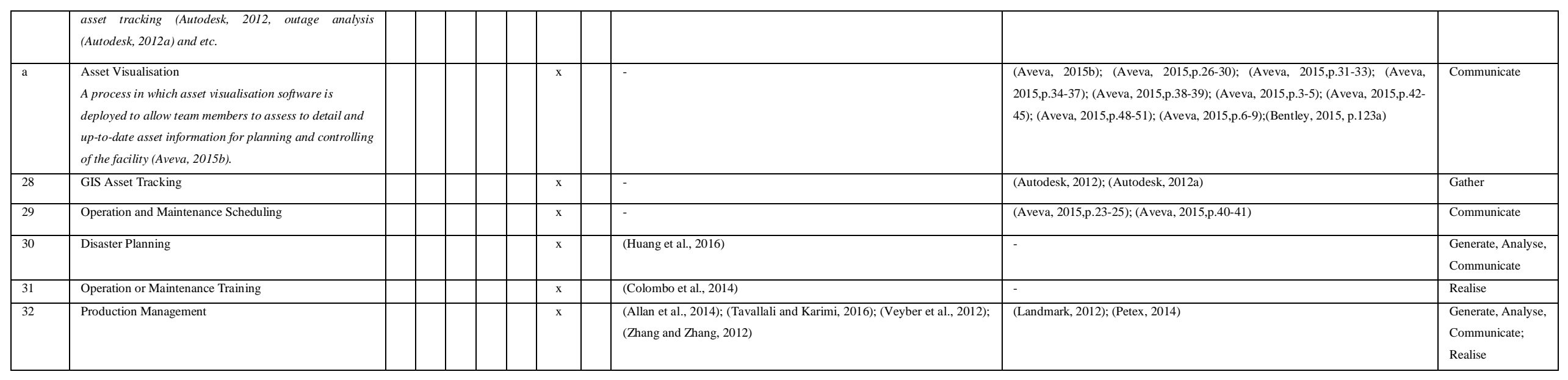


By streamlining the table 5 and 6, there is a total of thirty-six (36) BIM and DMAT application (as shown in figure 4) which could be applied in the oil and gas industry.

Figure 4: Streamlined BIM and DMAT Uses for the Oil and Gas Industry

\begin{tabular}{|c|c|c|c|c|c|c|c|}
\hline \multirow{2}{*}{ Exploration } & \multirow{2}{*}{\multicolumn{2}{|c|}{ Appraisal/Plan }} & \multicolumn{3}{|c|}{ Development } & \multirow{2}{*}{$\begin{array}{c}\text { Production, Operate and } \\
\text { Maintain }\end{array}$} & \multirow{2}{*}{$\begin{array}{l}\text { Abandonment } \\
\text { /Demolition }\end{array}$} \\
\hline & & & Design & Procure & Construct & & \\
\hline \multicolumn{7}{|c|}{ Geological Modeling } & \\
\hline \multicolumn{7}{|c|}{ Reservoir Modeling } & \\
\hline \multicolumn{7}{|c|}{ Data/ Information Management } & \\
\hline & \multicolumn{6}{|l|}{ Well Planning } & \\
\hline & \multicolumn{6}{|c|}{ Subsurface Model Review } & \\
\hline & \multicolumn{6}{|c|}{ Drilling Operation } & \\
\hline & & \multicolumn{2}{|c|}{ Economic Evaluation } & & & & \\
\hline & & \multicolumn{5}{|c|}{ Existing Conditions Modeling } & \\
\hline & & \multicolumn{2}{|c|}{ Site Analysis } & & & & \\
\hline & & \multicolumn{5}{|c|}{ Cost Estimation (5D) } & \\
\hline & & \multicolumn{4}{|c|}{ Phase Planning (4D) } & & \\
\hline & & \multicolumn{2}{|c|}{ Programming } & & & & \\
\hline & & \multicolumn{4}{|c|}{ Design Authoring } & & \\
\hline & & \multicolumn{2}{|c|}{ Design Reviews } & & & & \\
\hline & & \multicolumn{2}{|c|}{ Modeling, Instumentation and Diagram } & & & & \\
\hline & & & Design and Engineering Analysis & & & & \\
\hline & & & Offshore Structural Analysis & & & & \\
\hline & & & $\begin{array}{l}\text { Spatial, Cable and Raceway System } \\
\text { Analysis }\end{array}$ & & & & \\
\hline & & & Process Analysis & & & & \\
\hline & & & Material and Pipe Stress Analysis & & & & \\
\hline & & & Code Validation/ Compliance Checking & & & & \\
\hline & & & Design Documents & & & & \\
\hline & & & Clash Detection/ Design Coordination & & & & \\
\hline & & & & Digital Fab & rication & & \\
\hline & & & & Subcontra & Ictor Coordination/Management & & \\
\hline & & & & Material N & hanagement & & \\
\hline & & & & Equipmen & it Management & & \\
\hline & & & & & Constructability Review & & \\
\hline & & & & & $\begin{array}{l}\text { Site Utilisation Planning/ Logstic } \\
\text { Planning }\end{array}$ & & \\
\hline & & & & & $\begin{array}{l}\text { 3D Control and Planning (Digital } \\
\text { Layout)/ In field Construction Layout }\end{array}$ & & \\
\hline & & & & & Lift Planning & & \\
\hline & & & & & Progress Tracking & & \\
\hline & & & & & $\begin{array}{l}\text { Safety/ Safety Planning/Site Safety } \\
\text { Review }\end{array}$ & & \\
\hline & Streamlined BIM anc & DMAT & & & Construction System Design & & \\
\hline & Distinguished DMAT & & & & Field and Management Tracking & & \\
\hline & & & & & Field Supplements & & \\
\hline & & & & & As-Built Modeling/ Deconstruction N & Modeing & \\
\hline & & & & & Project Completion/Commissioning & & \\
\hline & & & & & & Asset Management & \\
\hline & & & & & & GIS Asset Tracking & \\
\hline & & & & & & $\begin{array}{l}\text { Operation and Maintenance } \\
\text { Scheduling }\end{array}$ & \\
\hline & & & & & & Operation and Maintenance Training & \\
\hline & & & & & & Disaster Planning & \\
\hline & & & & & & Assessment Models & \\
\hline & & & & & & Space and Management Tracking & \\
\hline & & & & & & Resiliency Modeling & \\
\hline & & & & & & $\begin{array}{l}\text { Transportation/ Logistic Management } \\
\text { System }\end{array}$ & \\
\hline & & & & & & Production Management & \\
\hline
\end{tabular}

\subsection{Exploration/Appraisal/Plan}


Distinguished DMAT application shown in Figure 4 indicates that the practices which are commonly applied in the oil and gas industry but are rarely adopted in the built environment such as for the building and infrastructure projects. These include geological modeling, reservoir modeling, well planning, subsurface model review, drilling operation in the exploration and appraisal phases. These DMAT applications are distinguished from the BIM uses as it is not adequate to be adopted by the building and infrastructure projects due to the natural work process. These DMAT practices are mainly used in (1) exploration and production, and (2) process and production facility. Besides, sustainability evaluation is important to most of the building construction as it is the significant process informing the life-cycle cost of a building (Gourlis and Kovacic, 2016). However, for the oil and gas industry, evaluating the life cycle cost such as the capital, operation and production costs of the projects is the ultimate aim. Accurate economic models embedded in the process modeling is essential in assessing the viability of the oil and gas facilities such as for the LNG projects (Beck, 2011).

BIM and DMAT application in the oil and gas industry for data and information management become prominent. Some evidence of this application include hybrid cloud computing system (Bentley, 2012, p.27, p. 105) was deployed to accelerate communication across the project teams; for energy refinery in Alberta, Canada, an innovated information plant management system was established to gather, store and connect the facility's technical data, engineering resource planning information, and documents in a single, reliable system supporting the day-to-day operations and maintenance decisions; and the system encompasses electronic documentation management system, lifecycle server, SAP asset management system and plant design tools (Bentley, 2013, p. 26). Also, a master tag registry and engineering data warehouse were developed in Queensland Curtis LNG project to supply the commissioning team with critical information related to various systems, tags, and documents (Bentley, 2014, p.11 and p.73).

During the feasibility stage, existing conditions modeling and site analysis are required to model the existing site and the facilities in the surrounding for project master planning. However, these uses are not apparent in the oil and gas industry. Only a case study demonstrated the development of 3D model using BIM tool to 
produce photomontages for inclusion in the environmental impact statement (Ward et. al., 2014). The majority of the existing conditions modeling are used for modeling the as-built oil and gas facilities. The adoption of the laser scanning for develop existing 3D models are gaining important in the oil and gas projects (Aveva, 2015a; Aveva, 2015, p.10-12; Aveva, 2015, p.13-15; Aveva, 2015, p.16-19; Aveva, 2015, p.26-30; Aveva, 2015, p.3-5; Bentley, 2012, p. 109; Bentley, 2014, p.98; Intergraph, 2014a) as there are getting more facilities required alterations and refurbishments. The laser scan data is easily imported into the design software and could be viewed effortlessly by the designers (Aveva, 2015, p.13-15). For process facility located in Bakersfield, California, laser scanning was utilised as verification tools at fabrication and construction process. Laser scan data in fabrication shop was imported to check against any deviations of the design model by informing decisions to reject or accept non-compliant piping components (Aveva, 2015, p. 16-19). Nevertheless, BIM uses such as cost estimating using model-based estimating software for 5D cost analysis and update the cost when there are changes made to the design (NYCDDC, 2012); and programming to track the design space (Harvard, 2016) which are important in planning a facility are not evident in the oil and gas projects.

\subsection{Design}

The practices of the oil and gas industry in modeling its facility is distinguished with that of the BIM in the built environment. The main focus of the oil and gas projects is to develop logic models so that the schematic design diagrams for piping and other MEP components are built according to the functional requirements of a facility and without any deviations among the facility elements. The plant life cycle management model used by the oil and gas projects enabled multi-disciplinary teams design simultaneously in a collaboration platform. The oil and gas industry is moving towards design integration. Diagram of engineering design could easily export information to other software and integrate with other engineering design tool (Aveva, 2015a; Aveva, 2015, p.10-12; Aveva, 2015, p. 13-15; Aveva, 2015, p. 26-30). 
Apart from that, the use of 4D modeling for planning, scheduling and sequencing the works in the oil and gas industry is also noticeable. A real-time pipe tracking system which utilised the radio-frequency identification (RFID) and 3D digital models in a handheld mobile device was developed to allow more efficient task management (Kim et al., 2013). Also, a 4D model for scheduling activity and operation of mega LNG construction projects was proposed to improve process planning and control (Zhou et al., 2015a). The engineering data such as the 3D model, piping isometrics and structural steel data were exported to a scheduling tool to create field installation work packages from a virtual construction model (Bentley, 2013, p.62). Another two important functions of BIM are the design review and design authoring which are commonly used in the oil and gas industry. Design review tool was deployed to review the plant design so that installation errors could be reduced (Aveva, 2015a). Design authoring is also used heavily in the oil and gas projects as it is the tool which adds richness of information in the oil and gas facility model. One of the examples is that the tool was used to enable the structure and piping design information to be integrated into the model (Bentley, 2012, p. 105).

Some distinguished DMAT uses which are not commonly used in the built environment include offshore structural analysis; spatial, cable and raceway system analysis; and process analysis. Besides, code checking, design documents and clash detection are the important DMAT uses which are usually embedded into the design software as parts of their supplementary functions. It is important to note that BIM is not about the technology, but it improves project management and collaboration among multi-disciplinary teams. To optimise the functions of the BIM and DMAT such as the clash detection, the regular meeting may be necessary to discuss the collaboration process among different design disciplines.

\subsection{Procure}

Modular construction is very common in the oil and gas projects. Several examples of modularisation strategies for steel designs have been proposed to maximise project savings of the oil and gas projects (Bedair, 2014). It is evident that digital fabrication has become important in the oil and gas industry, particularly in the 
steel fabrication components. Corrib onshore gas pipeline project deployed digital fabrication software (Ward et. al., 2014) to provide rapid detailing automation, automatic fabrication shop drawings and computer numeric control (CNC) machinery production deliverables. The software allows effective collaboration between engineers, detailers and fabricators.

Also, the information of plant life cycle model could be exported to into the oil and gas enterprise software for resource management such as the subcontractor and/or supplier management, material management and equipment management. In the BIM context, subcontractor coordination means it is a process of coordination among subcontractor for reviewing the design and optimising the scheduling prior to installations (NATSPEC, 2016). However, this process is not observable neither in the DMAT academic publications nor DMAT vendor case studies. This may due to both sources are technology-oriented, therefore, it is hard to find the discussion on the technology management practices in the oil and gas projects.

In the research and development, a conceptual framework was proposed to assure modular construction quality through introducing a situation awareness construction environment with well-defined sensing and tracking technologies (Chi et. al., 2015). A study investigated the RFID solutions was also conducted to identify the positions of onsite materials and components (Trujens et al., 2014). In practice, various procurement software were adopted in the oil and gas projects such as VPRM procurement and logistics (Aveva, 2015, p.48-51), oracle primavera (Aveva, 2015, p.24-27) and smartplant materials. With the material and supplier/ subcontractor management tool, bills of materials are extracted from the plant design tool to verify its completeness in the tool; supplier past performance can be assessed, new suppliers can be selected based on the selection criteria and maintain their record in the tool; the tool can also allow material status to be tracked, record, updated and activities from inviting subcontractor to manage the sub-contracting are also the functions of the tool (Intergraph, 2013). An integrated supplier management system was set up to include an eSupplier portal, activities from a request for quotation (RFQ)s to award, all post-agreement workflows, and progress control for each subcontract. This allows teams to collaborate more effectively across the engineering, procurement, and construction disciplines (Intergraph 
2015). The integrated supplier and subcontractor management were used in Thailand where the procurement office in Bangkok would have to handle suppliers in the Sattahip onshore base to support Bualuang wellhead project (Aveva 2015, p.40-41).4D modeling and mobile tools were deployed to manage and schedule the equipment for the construction of a new facility to connect to the existing oil and gas facility (Bentley, 2015, p.13).

\subsection{Construct}

Constructability review is important to the design and construction of the oil and gas projects. 4D modeling was used by Abreu e Lima refinery (Synchro, 2015) to analyse the execution and concreting sequence of the ramp and the substation implementation. Wang et al. (2014a) proposed the use of AR and BIM to enable walk-through functionality for facilitating design and constructability review process on the site. Apart from constructability review, the integration of these tools allows on-site progress monitoring to detect real problems, such as low productivity and the tendency of committing an error in assembly. Nevertheless, other BIM uses are not apparent in the oil and gas projects. The BIM use in planning and controlling the construction layout, logistic planning, lift planning and construction system design are not observable in the study. Construction system design is particular significant to the oil and gas projects given the complexity of the design and construction of the facilities. With the adoption of the construction system design, complex facility system such as modular components, formwork and scaffolding can be modeled to improve productivity and safety (NATSPEC, 2016).

Safety element is one of the main concerns of the oil and gas industry. 4D modeling was deployed to sequence the work packages in the NAG Project at the ExxonMobil facility in Texas enabling planning for access and egress routes that contributed to maintaining safety and reducing risk (Bentley, 2015, p.13). The 3D model was also deployed innovatively to review the operational and safety aspects of the surrounding during the design phase (Ward et. al., 2014) and the model could be coupled with various tools such as AR (Albert et.al., 2014; Chen et al., 2015), and hybrid-desk in a semi-immersive environment (Carvalho et al., 2012). 
For the completion and commissioning management system (CCMS), the common practices for the built environment sector is the Construction Operations Building Information Exchange (COBie), which is a non-proprietary platform for the exchange of life cycle data needed by facility managers (Kensek, 2015) and it was developed by a number of US public agencies to improve the handover process to building owner-operators (Buxton, 2015). For the oil and gas projects, the industry has their own commissioning system which differs from the building. The facilities and data format involve in the oil and gas projects are large and complex, hence, a real-time tracking system for project commissioning is more appropriate to ensure fast and accurate delivery. The tools carry similar functions of the BIM use such as the field and management tracking and prepare for project completion and commissioning. The examples of common CCMS system used in the oil and gas projects include WinPCS, ContinuumEdge (CE) and qedi.

\subsection{Production, maintain and operate}

Pertaining to the asset management, the oil and gas projects have a more complex facility management system. Enterprise asset management was deployed by the oil and gas exploration and production firm for (1) procurement and materials management; and (2) maintenance planning (Aveva, 2015, p.40-41). It also referred to Computerised Maintenance Management (CMM) system which was used to order materials from anywhere and track the delivery status enabled the operators to take informed actions to reduce the impact on operations. The system could also integrate with another system to ensure the reliable information provided for shutdown maintenance planning or any unplanned downtime. GIS asset tracking was deployed to enable safer and better gas pipeline management in Romania. An integrated 3D map, map server system, pipeline management system and sensors tracking system were established to manage the asset updates (Autodesk, 2012). Another similar system was used to analyse the outage which enabled better customer service (Autodesk, 2012a).

For operation and maintenance training, it is observed that the immersive virtual reality (IVR) which deployed the 3D plant model was proposed to enable the control-room operator (CROP) and field operator (FOP) to be trained 
simultaneously. Besides, the IVR enables the performance to be assessed by eliminating the subjectivity and the trainees were trained under an experimental approach instead of classical approach (Colombo et al., 2014). For disaster planning, a 3D visualisation model was integrated with other advanced technologies to monitor and forecast the disaster. By integrating sensor technologies, spatial information technologies, 3D visualisation technologies, and a landslideforecasting model, it was used to monitor and forecast landslides in the Danjiangkou Reservoir area (Huang et. al., 2016). In the context of BIM, disaster planning is in connection with the BIM use with building management system for emergency response planning (NATSPEC, 2016) which is not apparent in the oil and gas projects. Other BIM uses such as assessment models, space and management tracking, resiliency modeling and logistics management system are not apparent in the oil and gas projects.

Production management is a distinguished DMAT use which is not commonly applied in the built environment. An integrated system which consisted of an upto-date 3D geological model, production management software such as ERP system (Veyber et al., 2012), grid-based production management system (Zhang and Zhang, 2012) was proposed for the upstream oil and gas production management. Information extracted from well data was used to establish cost estimate of drilling and production via Cost Estimate Request (CER) database. The combination of Well Planner and FracScheduler was also proposed to streamline the production scheduling and value stream discipline so as to determine which well is ready for rig work (Allan et al 2014).

\subsection{Demolition}

When the oil and gas field is near the end of its life cycle, it shall prepare for restoring the site to its original condition. The process and production plants would also have to be dismantled. Both the BIM and DMAT uses are not apparent at this stage. The existing conditions modeling and/or deconstruction modeling (Ward et al., 2014) could be used to present the existing as-built model and site conditions to plan for the demolition works. Other DMAT and BIM uses which were used for 
planning, designing and construction works could be possibly used in this stage to streamline the demolition process.

\subsection{Summary}

In the planning and design stage, while design reviews, 3D plant modeling, phase planning (4D), design coordination, design documents and code checking become prominent in the oil and gas projects, other BIM uses such as existing conditions modelling, site analysis, cost analysis (5D) and programming for assessing design space can also be deployed to provide more reliable information for the owners, designers and contractors (if they are involved during the early design stage) to make an informed decision on the oil and gas project development. Existing conditions modeling should not only use to model the as-built oil and gas facilities but it should extend to model the surrounding site conditions during the project planning stage and fabricated items before delivering them to a site. During the procure stage, digital fabrication is an essential element to speed up the oil and gas projects while reducing the deviations among the design, fabrications and installations. Subcontractor and supplier management, material and equipment management are also significant to smoothen the procurement process. However, subcontractor coordination is important too to ensure effective model coordination and resolve constructability issues between the different trades. In the construction stage, apart from constructability reviews, progress tracking, safety planning and field and management tracking which are commonly used by the oil and gas projects to improve project performance, other BIM uses such as planning and controlling the construction layout through creation of digital layout; logistic planning which involved detailed logistic objects that linked to construction schedule (4D model); lift planning model that allows the structure engineers and experienced site personnel to communicate the lift plan execution; and construction system design for modeling the complex construction could be implemented to improve the overall productivity of the construction process. In the production, operation and maintenance phase, it is noticed that asset management, GIS asset tracking, operation and maintenance training and production management are usually implemented in the oil and gas projects. Other uses such as assessment models for efficient field data collection; disaster planning for emergency response; 
space and management tracking to evaluate, manage and track the existing use space and associated resources within an oil and gas facility; resiliency modelling for the remote areas subject to environmental change; and logistics management system to support entire transportation lifecycle from creating the least cost shipment plans to monitoring the whole distribution network proactively can also be adopted to improve overall operation efficiency. As in the final stage of a project life cycle, existing conditions modeling and de-construction model can be used to plan for the demolition works. Figure 5 shows the potential BIM and DMAT uses for performance improvement in the oil and gas projects.

Figure 5: Potential BIM and DMAT Uses for the Oil and Gas Projects

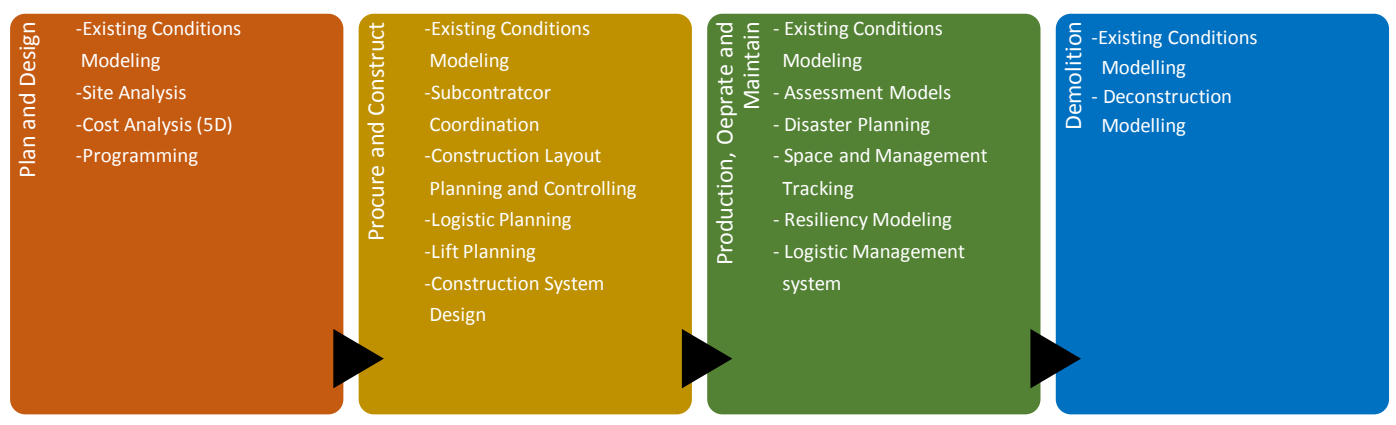

\section{Conclusion and Recommendations}

The conducted literature review of twenty-eight (28) BIM guidelines, eighty-three (83) DMAT academic publications and one hundred and one (101) DMAT vendor case studies have streamlined thirty-six (36) BIM and DMAT uses for oil and gas projects. The findings reveal that they are many potential applications of DMAT and BIM uses (figure 5) can be applied in the oil and gas projects for performance improvement. Data and information management system which are commonly implemented in the oil and gas projects could be deployed in the built environment sector to improve the collaboration among multi-disciplinary teams from planning until operation and maintenance phase.

Few limitations need to be considered in this research. This study does not take into account the effective measures of the BIM and DMAT uses. The highlighted 
technology practices are only applicable to the technologies, which have a similar taxonomy of (1) DMAT such as the geometry bedding used for oil and gas exploration and production and also PLM system used for design, construction and operation, and (2) BIM. The scope of this study is not extended to the common enterprise computational tools such as the enterprise resource planning (ERP) which is commonly used in the oil and gas firms. Also, the study may overlook some BIM and DMAT uses as per the BIM guidelines, DMAT academic publications and vendor case studies. Future studies may investigate the efficiency use of the BIM and DMAT technologies for the oil and gas project improvement; examine the potential DMAT applications in the built environment sector; and study the technical possibility of linking the PLM, BIM and ERP system for performance improvement in both the oil and gas and built environment sectors.

Acknowledgement

We are grateful to Gary Tan, an IT specialist of oil and gas projects for his time and suggestions of improvement of our paper. This paper was inspired by the preparatory research for the author's $\mathrm{PhD}$ project which is co-funded by Curtin University and Australian Research Council (ARC) linkage scholarship \#53187.

Compliance with Ethical Standards

Human Participants Nor Animals

The research does not involve neither human participants nor animals

Informed Consent

All the authors are informed and provided their consent.

\section{Conflict of Interest}

The authors declare that they have no conflict of interest.

\section{References}


Abdideh, M. and Bargahi, D., 2012. Designing a 3D model for the prediction of the top of formation in oil fields using geostatistical methods. Geocarto International, 27(7), pp.569-579.

AEC UK, 2015. AEC (UK ) BIM Protocol, London, UK.

AGC, 2009. The Contractor's Guide to BIM, Associated General Contractors of America, Virginia, USA.

Albert, A., Hallowell, M.R., Kleiner, B., Chen, A. and Golparvar-Fard, M., 2014. Enhancing construction hazard recognition with high-fidelity augmented virtuality. Journal of Construction Engineering and Management, 140(7), p.04014024.

Allan, M.E., Reese, D.W. and Gold, D.K., 2014, April. Application of Toyota's Principles and Lean Processes to Reservoir Management: More Tools to Overload the Toolbox or a Step Change in Our Business?. In SPE Western Regional \& AAPG Pacific Section Meeting 2013 Joint Technical Conference. Society of Petroleum Engineers.

Amanipoor, H., Ghafoori, M. and Lashkaripour, G.R., 2013. The application of géostatistical methods to prepare the 3D petrophysical model of oil reservoir.Open Journal of Geology, 3, 7-18

Amoyedo, S.O., Ekut, E., Salami, R., Goncalves-Ferreira, L. and Desegaulx, P., 2014, October. Time Lapse (4D) Seismic for Reservoir Management: Case Studies from Offshore Niger Delta, Nigeria. In SPE Annual Technical Conference and Exhibition. Society of Petroleum Engineers.

Ask, M.V., Ask, D., Elvebakk, H. and Olesen, O., 2015. Stress Analysis in Boreholes Drag Bh and Leknes Bh, Nordland, North Norway. Rock Mechanics and Rock Engineering, 48(4), pp.1475-1484.

Aspentech, 2015. Global Refiner Deploys Cost Estimation Solution to Accelerate Decision Making and Lower Costs. Aspen Technology, Burlington, Massachusetts, United States

Aspentech, 2015a. Process Ecology Reduces Capital Costs and Prevents Downtime by Using Aspen HYSYS® Family. Aspen Technology, Burlington, Massachusetts, United States 
Aspentech, 2015b. EPC Leader Adopts Integrated Engineering Solution to Drive

Growth in FEED Business. Aspen Technology, Burlington, Massachusetts, United States

Aspentech, 2016. Gas-to-Liquid Technology Provider Scales-up and Optimizes Plant Design Using the aspenONE® Engineering Suite, Aspen Technology, Burlington, Massachusetts, United States.

Autodesk, 2012. A new way of working: GDF SUEZ Energy Romania Customer Success Story. Autodesk, USA.

Autodesk, 2012a. Connecting the enterprise: Okaloosa Gas District Customer Success Story. Autodesk, USA.

Autodesk, 2013. Dynamic design drives dynamic growth: Civil \& Environmental Consultants, Inc. (CEC), Autodesk, USA.

Autodesk, 2013a. Weeks of Work Reduced to Minutes. NATCO Group, Inc. Customer Success Story, Autodesk, USA.

Aveva, 2012. AVEVA releases Structural Analysis Interface - SP for STAAD.Pro.

23 August, Press release. AVEVA. Retrieved from : http://www.aveva.com/en/News-Events/Press-Releases/Press-Releases2012/Corporate/AVEVA_releases_SAI-SP.aspx [ 15 June 2016]

Aveva, 2015. AVEVA World Focus. Oil \& Gas Projects, innovation and experiences from past issues of AVEVA World Magazine. Aveva, Cambridge, UK.

Aveva, 2015a. AVEVA E3D increases profitability and competitiveness at Tekfen Engineering, Turkey's largest engineering company: Aveva Case study, Cambridge, UK.

Aveva, 2015b. Information Management Delivers Clear Benefits for Petroleum Development Oman: Aveva Case Study. Aveva, Cambridge, UK.

Aveva, 2015c. AVEVA Engineering enables six-fold growth at Giprogazoochistka. Aveva, Cambridge, UK.

Aveva, 2015d. Integrated Engineering and Design: An AVEVA solution for capital and brownfield projects. Aveva Group plc, Cambridge, UK.

Azhar, S., 2011. Building information modeling (BIM): Trends, benefits, risks, and challenges for the AEC industry. Leadership and Management in Engineering, 11(3), pp.241-252. 
Baaziz, A. and Quoniam, L., 2013. How to use Big Data technologies to optimize operations in Upstream Petroleum Industry. Baaziz, A., \& Quoniam, L. (2013). How to use Big Data technologies to optimize operations in Upstream Petroleum Industry. International Journal of Innovation-IJI, 1(1), pp.19-25.

BCA, 2013. Singapore BIM Guide, Building and Construction Authority: Singapore.

Beck, R., 2011. Improve decision-making for LNG projects via an integrated technology: This approach to modeling and economics cuts through the complexity of project capital investment. Hydrocarbon processing, 90(7), pp.51-54.

Bedair, O., 2014. Cost effective modularization strategies for industrial facilities used in mega Oil \& gas projects. Recent Patents on Engineering, 8(2), pp.120-132.

Beeson, D., Hoffman, K., Larue, D., McNaboe, J. and Singer, J., 2014. Creation and utility of a large fit-for-purpose earth model in a giant mature field: Kern River field, California. AAPG Bulletin, 98(7), pp.1305-1324.

Bentley, 2012. The Year in Infrastructure. Bentley Systems, Incorporated. Exton, Pennsylvania, USA.

Bentley, 2013. The Year in Infrastructure. Bentley Systems, Incorporated. Exton, Pennsylvania, USA.

Bentley, 2014. The Year in Infrastructure. Bentley Systems, Incorporated. Exton, Pennsylvania, USA.

Bentley, 2015. The Year in Infrastructure. Bentley Systems, Incorporated. Exton, Pennsylvania, USA.

BHP, 2015. Speaking Oil and Gas. BHP Biliton Petroleum Pty Ltd, Australia.

Brigaud, B., Vincent, B., Durlet, C., Deconinck, J.F., Jobard, E., Pickard, N., Yven, B. and Landrein, P., 2014. Characterization and origin of permeabilityporosity heterogeneity in shallow-marine carbonates: From core scale to 3D reservoir dimension (Middle Jurassic, Paris Basin, France). Marine and Petroleum Geology, 57, pp.631-651.

Bruns, B., Di Primio, R., Berner, U. and Littke, R., 2013. Petroleum system evolution in the inverted Lower Saxony Basin, northwest Germany: a 3D basin modeling study. Geofluids, 13(2), pp.246-271. 
Buxton, P. ed., 2015. Metric Handbook: Planning and Design Data. Routledge.5th Ed. Routledge, New York.

Cacace, M. and Blöcher, G., 2015. MeshIt - a software for three dimensional volumetric meshing of complex faulted reservoirs. Environmental Earth Sciences, 74(6), pp.5191-5209.

Carvalho, F.G., Trevisan, D.G. and Raposo, A., 2012. Toward the design of transitional interfaces: an exploratory study on a semi-immersive hybrid user interface. Virtual Reality, 16(4), pp.271-288.

CFM, 2010. The VA BIM Guide, Department of Veterans Affairs, Construction \& Facilities Management, Washington DC, USA.

Chelmis, C., Zhao, J., Sorathia, V.S., Suchindra, A. and Prasanna, V.K., 2013. Toward an Automatic Metadata Management Framework for Smart Oil Fields. SPE Economics \& Management, 5(01), pp.33-43.

Chemali, R., Semac, W., Balliet, R., Cooper, P., Torres, D. and Jones, C., 2014. Formation-Evaluation Challenges and Opportunities in Deepwater. Petrophysics, 55(02), pp.124-135.

Chen, Y.C., Chi, H.L., Kang, S.C. and Hsieh, S.H., 2015. Attention-Based User Interface Design for a Tele-Operated Crane. Journal of Computing in Civil Engineering, 30(3), p.04015030.

Chi, H.L., Wang, J., Wang, X., Truijens, M. and Yung, P., 2015. A conceptual framework of quality-assured fabrication, delivery and installation processes for liquefied natural gas (LNG) plant construction. Journal of Intelligent \& Robotic Systems, 79(3-4), pp.433-448.

Chong, H.Y., Lopez, R., Wang, J., Wang, X. and Zhao, Z., 2016. Comparative Analysis on the Adoption and Use of BIM in Road Infrastructure Projects. Journal of Management in Engineering, p.05016021.

Chong, H.Y. and Wang, X., 2016a. The outlook of building information modeling for sustainable development. Clean Technologies and Environmental Policy, pp.1-11.

COD , 2011. BIM GUIDE, College of the Desert, Palm Desert, USA.

Colombo, S., Nazir, S. and Manca, D., 2014. Immersive Virtual Reality for Training and Decision Making: Preliminary Results of Experiments Performed With a Plant Simulator. SPE Economics \& Management, 6(04), pp.165-172. 
COSA, 2011. Building Information Modeling (BIM) Development Criteria and Standards for Design \& Construction Projects. COSA BIM Standards. City of San Antonio, City of San Antonio, San Antonio, Texas.

CRC, 2009. Naational Guidelines for Digital Modeling, CRC Construction Innovation, Queensland, Australia.

Credit Suisse, 2014. Quarterly - Brazil tracker, Equity Research, Integrated Oil and Gas, 20 January, Credit Suisse Securities Research and Analystics.

Cuba, P.H., Miskimins, J.L., Anderson, D.S. and Carr, M., 2012, January.Impacts of Diverse Fluvial Depositional Environments on Hydraulic Fracture Growth in Tight Gas Reservoirs. In SPE Hydraulic Fracturing Technology Conference. Society of Petroleum Engineers.

Darko, E., 2014. Short guide summarising the oil and gas industry lifecycle for a non-technical audience.Overseas Development Institute, London, UK.

de Oliveira Miranda, A.C., Lira, W.W.M., Marques, R.C., Pereira, A.M.B., Cavalcante-Neto, J.B. and Martha, L.F., 2015. Finite element mesh generation for subsurface simulation models. Engineering with Computers, 31(2), pp.305-324.

Do Couto, D., Gumiaux, C., Jolivet, L., Augier, R., Lebret, N., Folcher, N., Jouannic, G., Suc, J.P. and Gorini, C., 2015. 3D modelling of the Sorbas Basin (Spain): new constraints on the Messinian Erosional Surface morphology. Marine and Petroleum Geology, 66, pp.101-116.

DOA/DSF, 2012. BIM Guidelines \& Standards for ARCHITECTS and ENGINEERS Department of Administration, Division of State Facilities, Wisconsin, USA

Dong, T., He, S., Wang, D. and Hou, Y., 2014. Hydrocarbon migration and accumulation in the Upper Cretaceous Qingshankou Formation, Changling Sag, southern Songliao Basin: Insights from integrated analyses of fluid inclusion, oil source correlation and basin modelling. Journal of Asian Earth Sciences, 90, pp.77-87.

Downton, G., 2015. Systems Modeling and Design of Automated-DirectionalDrilling Systems. SPE Drilling \& Completion, 30(03), pp.212-232.

Duran, E.R., di Primio, R., Anka, Z., Stoddart, D. and Horsfield, B., 2013. 3D-basin modelling of the Hammerfest Basin (southwestern Barents Sea): A 
quantitative assessment of petroleum generation, migration and leakage. Marine and petroleum geology, 45, pp.281-303.

EY, 2014. Spotlight on oil and gas megaprojects. Ernst and Young Global Limited, London, UK.

Fayemi, O. and Di, Q., 2016. 2D Multitransient Electromagnetic Response Modeling of South China Shale Gas Earth Model Using an Approximation of Finite Difference Time Domain with Uniaxial Perfectly Matched Layer. Discrete Dynamics in Nature and Society, 2016.

Fegh, A., Riahi, M.A. and Norouzi, G.H., 2013. Permeability prediction and construction of 3D geological model: application of neural networks and stochastic approaches in an Iranian gas reservoir. Neural Computing and Applications, 23(6), pp.1763-1770.

FMS, 2012. BIM Guidelines, University of Southern California Facilities Management Services, Los Angeles, USA.

Geiger, S., Lord, G. and Tambue, A., 2012. Exponential time integrators for stochastic partial differential equations in 3D reservoir simulation. Computational Geosciences, 16(2), pp.323-334.

Glegola, M.A., Ditmar, P., Hanea, R., Eiken, O., Vossepoel, F.C., Arts, R. and Klees, R., 2012. History Matching Time-Lapse Surface-Gravity and WellPressure Data With Ensemble Smoother for Estimating Gasfield Aquifer Support--A 3D Numerical Study. SPE Journal, 17(04), pp.966-980.

Gourlis, G. and Kovacic, I., 2016. Building Information Modelling for analysis of energy efficient industrial buildings-A case study. Renewable and Sustainable Energy Reviews.

GSA, 2015. National 3D-4D BIM Program, United States General Services Administration, Washington, USA.

GSFIC, 2013. BIM Guide, Georgia State Financing and Investment Commission, Georgia, USA.

GTFM, 2016. Georgia Tech BIM Requirements \& Guidelines for Architects, Engineers and Contractors, Georgia Tech Facilities Management, Georgia, USA.

Han, M.K., Kim, W.K. and Park, M.G., 2014. Development of a Collaboration System based on Mobile Framework in the Field of Ships and Marine 
Industry. International Journal of Multimedia and Ubiquitous Engineering, 9(4), pp.121-126.

Harvard, 2016. BIM Uses Guide, Harvard University Construction Management Council, Cambridge, USA.

He, W. and Wang, F.K., 2015. A Hybrid Cloud Model for Cloud Adoption by Multinational Enterprises. Journal of Global Information Management (JGIM), 23(1), pp.1-23.

HKCIC, 2015. CIC Building Information Modelling Standards (Phase One). Construction Industry Council, Wanchai, Hong Kong.

HM Government, 2013. Building Information Modeling. Industrial strategy: government and industry in partnership, Construction 2025, July 2013. London, UK.

Hu, G., Campbell, M. and Huang, C., 2014. Dynamic Plastic Deformation of Deepwater Steel Catenary Risers Under Extreme Cyclic Compressive Loading. Oil and Gas Facilities, 4(01), pp.73-79.

Huang, H., Ni, J., Zhang, Y., Qian, T., Shen, D. and Wang, J., 2016. Web3DGISBased System for Reservoir Landslide Monitoring and Early Warning. Applied Sciences, 6(2), p.44.

Infrastructure Australia, 2016. Australian Infrastructure Plan. Priorities and reforms for our nation's future, New South Wales, Australia.

Intergraph 2015a. Case Study: Eco Fox, Italy. Madison, Alabama, United States.

Intergraph 2015a. Case Study: Vietsovpetro, Vietnam. Madison, Alabama, United States.

Intergraph, 2012. Case study: China National Offshore Oil Corporation, China. Intergraph Corporation. Madison, Alabama, United States.

Intergraph, 2013. Case study: OHL Industrial, Spain. Intergraph Corporation. Madison, Alabama, United States.

Intergraph, 2013a. Case Study: Gasco, United Arab Emirates. Madison, Alabama, United States.

Intergraph, 2014. Case study: On Line Design \& Engineering Ltd., England. Madison, Alabama, United States.

Intergraph, 2014a. Case Study: Nortech, United Kingdom. Madison, Alabama, United States. 
Intergraph, 2015. Case Study: Leighton Uses SmartPlant ${ }^{\circledR}$ Materials to Assist in Securing New Contract on LNG Megaproject. Madison, Alabama, United States.

Intergraph, 2016. Grenland Group, Norway. Madison, Alabama, United States.

Intergraph, 2016a. Intergraph Aids Remote Engineering for Delta Hudson. Madison, Alabama, United States.

Intergraph, 2016b.ABB, Italy. Madison, Alabama, United States.

IU, 2015. BIM Guidelines \& Standards for Architects, Engineers, and Contractors. Indiana University, Indiana, United States.

Iversen, F., Gressgård, L.J., Thorogood, J., Balov, M.K. and Hepso, V., 2013. Drilling Automation: Potential for Human Error. SPE Drilling \& Completion, 28(01), pp.45-59.

Jain, R., Syal, S., Long, T.A., Wattenbarger, R.C. and Kosik, I.J., 2013. An integrated approach to design completions for horizontal wells for unconventional reservoirs. SPE Journal, 18(06), pp.1-026.

Kamali, M.R., Omidvar, A. and Kazemzadeh, E., 2013. 3D Geostatistical Modeling and Uncertainty Analysis in a Carbonate Reservoir, SW Iran. Journal of Geological Research, 2013.

Katterbauer, K., Hoteit, I. and Sun, S., 2015. History Matching of Electromagnetically Heated Reservoirs Incorporating Full-Wavefield Seismic and Electromagnetic imaging. SPE Journal.

Kensek, K., 2015. BIM Guidelines Inform Facilities Management Databases: A Case Study over Time. Buildings, 5(3), pp.899-916.

Kim, C.H., Kwon, S.W. and Cho, C.Y., 2013. Development of automated pipe spool monitoring system using RFID and 3D model for plant construction project. KSCE Journal of Civil Engineering, 17(5), pp.865-876.

Kim, J.D., Choi, S.B., Lee, J.M., Kim, M.K., Choi, S.C., Hwang, I.J. and Choi, J.B., 2014. Conceptual design of a web-based LNG plant management system through adoption of the integrated environment for design and maintenance. Journal of Mechanical Science and Technology, 28(9), pp.3759-3767.

King, M.J., Ballin, P.R., Bennis, C., Heath, D.E., Hiebert, A.D., McKenzie, W., Rainaud, J.F. and Schey, J., 2012. Reservoir modeling: From rescue to resqml. SPE Reservoir Evaluation \& Engineering, 15(02), pp.127-138. 
Kulga, K.S. and Menshikov, P.V., 2015. Computer-Aided Design of Layouts for Cutting Shells for Chemical and Oil-and-Gas Engineering Articles. Chemical and Petroleum Engineering, 51(7-8), pp.540-547.

Kvesić, M., Reimer, U., Froning, D., Lüke, L., Lehnert, W. and Stolten, D., 2012. 3D modeling of an HT-PEFC stack using reformate gas. International Journal of Hydrogen Energy, 37(17), pp.12438-12450.

LACCD, 2016. BIM Standard. Los Angeles Community College District, Los Angeles, USA.

Landmark, 2012. Real-Time Surveillance Optimizes Production at Black Hills E\&P. Halliburton, Houston, USA.

Landmark, 2016. Collaborative Well Solution Reduces Offshore Rig Time by 15 Days for NOC Off South America. Halliburton, Houston, USA.

Lee, D.Y., Chi, H.L., Wang, J., Wang, X. and Park, C.S., 2016. A linked data system framework for sharing construction defect information using ontologies and BIM environments. Automation in Construction, 68, pp.102113.

Li, H.Y., Chen, Y. and Zhao, D., 2013. The Design and Implementation of 3D Visualization Pipeline Information System Based on 2D Figures. In Applied Mechanics and Materials (Vol. 246, pp. 1241-1245). Trans Tech Publications. Lindsay, M.D., Jessell, M.W., Ailleres, L., Perrouty, S., de Kemp, E. and Betts, P.G., 2013. Geodiversity: exploration of 3D geological model space. Tectonophysics, 594, pp.27-37.

Liu, J., Huang, X., Wu, C., Cheng, W., Xiang, W. and Xia, H., 2012. From the area to the point-study on the key technology of 3D geological hazard modeling in Three Gorges Reservoir area. Journal of Earth Science, 23, pp.199-206.

Ma, J.Y., 2014. Fast Production Recovery of a Typhoon-Damaged Oil Field in the South China Sea. Oil and Gas Facilities, 3(05), pp.66-71.

Marongiu-Porcu, A., Zhang, K., Gakhar, K., Porcu, M.M., Lee, D., Shan, D., Malpani, R., Pope, T., Sobernheim, D. and Acock, A., 2016, February. Advanced Modeling of Interwell Fracturing Interference: An Eagle Ford Shale Oil Study-Refracturing. In SPE Hydraulic Fracturing Technology Conference. Society of Petroleum Engineers.

MPA, 2015. Appendix A: MPA BIM Guidelines. Massachusets Port Authority, Boston, USA. 
Muley, P., Kulkarni, S., Kurhekar, R. and Thorat, S., 2014. 3D Virtual Glove for Data Logging and Pick and Place Robot. IJECCE, 5(2), pp.319-324.

Munoz-Garcia, E., 2014. Risk-Based Passive Fire-Protection Optimization. Oil and Gas Facilities, 3(01), pp.67-75.

Naji, H.S., Khalil, M.K., 2012. 3D geomodeling of the Lower Cretaceous oil reservoir, Masila oil field, Yemen. Arab J Geosci, 5:723-746.

National BIM Standard, 2015. National BIM Standard-United States® (NBIMSUS $^{\mathrm{TM}}$ ) Version 3, Washington, USA.

National BIM Standard, 2015. Practice Dcuments: The Uses of BIM. National BIM Standard - United States ${ }^{\circledR}$ Version 3, Washington, USA.

NATSPEC, 2016. NATSPEC National BIM Guide. NATSPEC Construction Information, Sydney, Australia.

NHBA, 2012. BoligBIM (BIM Manual), Boligprodusentene (Norwegian Home Builders Association), Oslo, Norway.

Nikolaou, M., 2013. Computer-aided process engineering in oil and gas production. Computers \& Chemical Engineering, 51, pp.96-101.

Norden, B., Förster, A., Behrends, K., Krause, K., Stecken, L. and Meyer, R., 2012. Geological 3-D model of the larger Altensalzwedel area, Germany, for temperature prognosis and reservoir simulation. Environmental Earth Sciences, 67(2), pp.511-526.

Norton, K.D., Saura, M.B. and Scholtz, C.R., 2014. Safety management systems at unregulated upstream oil and gas facilities. Process Safety Progress, 33(3), pp.259-264.

NRC, 2014. National BIM Guidelines and Case Studies for Infrastructure. Sustainable Built Environment National Research Centre, Perth, Australia.

NYCDDC, 2012. BIM Guidelines. Department Design and Construction, New York, United States.

NYCSCA, 2014. BIM Guidelines and Standards for Architects and Engineers, New York City School Construction Authority, New York, USA.

OFCC, 2012.BIM Protocol, State of Ohio Facilities Construction Commission, Ohio, USA.

Panfili, P., Cominelli, A., Calabrese, M., Albertini, C., Savitsky, A. and Leoni, G., 2012. Advanced upscaling for kashagan reservoir modeling. SPE Reservoir Evaluation \& Engineering, 15(02), pp.150-164. 
Paradigm, 2013. Paradigm plays an essential role in the GNS SCIENCE 4DTaranaki project.PESA News Resources, April/May, 2013, Perth, WA.

Paradigm, 2016.EarthStudy 360 Delivers New Information about Fractures in Carbonate Reservoirs. Paradigm, Houston, USA.

Paradigm, 2016a.Generating a Full Field Development Plan in a Highly Restricted Urban Drilling Location. Paradigm, Houston, USA.

Paradigm, 2016b.Paradigm SKUA Delivers a Full Static Model in a Highly Complex Structural Environment. Paradigm, Houston, USA.

Paradigm, 2016c.Combining Geostatistics with Seismic Attributes to Improve Reservoir Management Strategies: A Case Study from the Orinoco Petroleum Belt. Paradigm, Houston, USA.

Paris, L. and Cahay, M., 2014, May. Challenges in a Multi-Disciplinary Approach for Explosion Design of FLNG. In Offshore Technology Conference. Offshore Technology Conference.

Park, H.Y. and Datta-Gupta, A., 2013. Reservoir management using streamlinebased flood efficiency maps and application to rate optimization. Journal of Petroleum Science and Engineering, 109, pp.312-326.

Pathak, P.D., Kocurek, C.G. and Taylor, S.L., 2013. Design Method Combing API and ASME Codes for Subsea Equipment for HPHT Conditions Up to 25,000 psi Working Pressure and Temperature to 400 F.Offshore Technology Conference, Houston, 6-9 May.

Perrons, R.K. and Hems, A., 2013. Cloud computing in the upstream oil \& gas industry: A proposed way forward. Energy Policy, 56, pp.732-737.

Perrons, R.K. and Jensen, J.W., 2015. Data as an asset: What the oil and gas sector can learn from other industries about "Big Data". Energy Policy, 81, pp.117121.

Perrons, R.K. and Richards, M.G., 2013. Applying maintenance strategies from the space and satellite sector to the upstream oil and gas industry: A research agenda. Energy Policy, 61, pp.60-64.

Petex, 2014. Multi Well Allocation Using Digital Oilfield (DOF) Technology in the Norwegian Sea. Petroleum Experts, 2(1), Houston, USA.

Popa, A. and Cassidy, S., 2012. i-field Programs Enable Operational Excellence in a Challenging Environment--Pushing the Limits of Large Data Transfer for 
Real-Time Monitoring and Surveillance Operations in San Joaquin Valley.

SPE Economics \& Management, 4(02), pp.83-89.

PSU, 2011. BIM Execution Planing: BIM Uses. Penn State University, University Park, PA, USA.

Reid, S., Cann, G., 2016. The good, the bad and the ugly: The changing face of Australia's LNG production. Deloitte, Canberra, Australia.

Savazzi, S., Guardiano, S. and Spagnolini, U., 2013. Wireless sensor network modeling and deployment challenges in oil and gas refinery plants. International Journal of Distributed Sensor Networks, 2013.

Sawaryn, S.J., Pirie, L., Green, I., Scott, A., Cosgrove, B. and Emslie, I., 2014. Integration and assurance of well documents and data-Essential preparation for tomorrow. SPE Economics \& Management, 6(01), pp.3-14.

Schlumberger, 2012. Case study: Geomechanics and Drilling optimization Workflows improve horizontal Well Campaigns in Peru. Schlumberger, Houston, Texas, United States.

Schlumberger, 2013. Case study: Collaborative Visualization Environment Enhances Exploration at PetroSA. Schlumberger, Houston, Texas, United States.

Schlumberger, 2013a. Case study: AGIBA Optimises Drilling with Real-time Data. Schlumberger, Houston, Texas, United States.

Schlumberger, 2013b. Case study: Hidden Fault detection in haynesville Shale Prevents loss of $33 \%$ Gas Production. Schlumberger, Houston, Texas, United States.

Schlumberger, 2014. Case Study: 3D Geological Model Based on Sequence Stratigraphy Reduces Uncertainty in Deep Carbonate Reservoirs. Schlumberger, Houston, Texas, United States.

Schlumberger, 2014a. Case Study: GDF Suez Defines Key Drilling Investments with Collaborative Well Planning. Schlumberger, Houston, Texas, United States.

Schlumberger, 2015. Case Study: RWE Dea Streamlines Asset Data Management with eSearch Software Implementation. Schlumberger, Houston, Texas, United States. 
Schlumberger, 2015a. Case Study: Oil India Identifies Deep Exploration Targets Using Petrel Platform's Integration of Seismic and Well Data. Schlumberger, Houston, Texas, United States.

Schlumberger, 2015b. Case Study:Eni Deploys High Resolution Reservoir Simulator Across Complex Global Assets. Schlumberger, Houston, Texas, United States.

Schlumberger, 2016. Case Study:While Drilling Formation Evaluation and Interpretation Guides Geosteering to Target Zones, North Sea. Schlumberger, Houston, Texas, United States.

Schlumberger, 2016a. Case Study:Rashpetco Extends Development Plan by Updating Model in the Petrel Platform, Offshore Egypt. Schlumberger, Houston, Texas, United States.

Schlumberger, 2016b. Case Study:Petrel Platform Enables High-Resolution, Quantitative Modeling of Complex, Heterogeneous Reservoir. Schlumberger, Houston, Texas, United States.

SDCCD, 2012. BIM Standards for Architects, Engineers \& Contractors, San Diego Community College District, San Diego, USA.

SEC, 2013. First Steps to BIM Competence: A Guide for Specialist Contractors, Specialist Engineering Contractors' Group and BIM Academy at the University of Northumbria, Northumbria, UK.

Senel, O., Will, R. and Butsch, R.J., 2014. Integrated reservoir modeling at the Illinois Basin-Decatur Project. Greenhouse Gases: Science and Technology, 4(5), pp.662-684.

Shou, W., Wang, J., Wang, X. and Chong, H.Y., 2015. A comparative review of building information modelling implementation in building and infrastructure industries. Archives of computational methods in engineering, 22(2), pp.291-308.

Soleimani, M. and Shokri, B.J., 2015. 3D static reservoir modeling by geostatistical techniques used for reservoir characterization and data integration. Environmental Earth Sciences, 74(2), pp.1403-1414.

Statsbygg, 2012. Statsbygg BIM Manual, Statsbygg, Oslo, Norway.

Synchro 2014. Using Synchro in the life cycle of an EPC project. Case: TECAB (Expansion of the ground Terminal Cabiúnas ) for Petrobras S/A. Consórcio SPS, São Carlos, Brazil. 
Synchro 2015. Systems Development: Planning and BIM.Construções e Comércio Camargo Correa S.A., Brazil.

Tavallali, M.S. and Karimi, I.A., 2015. Integrated Oil Field Management-from Well Placement and Planning to Production Scheduling. Industrial \& Engineering Chemistry Research.

Tekla, 2016. Saipem Offshore. Trimble Solutions Corporation, Espoo. Finland.

Tekla, 2016a. Neste Oil Diesel production line. Trimble Solutions Corporation, Espoo. Finland.

Tekla, 2016b. Offshore Structures. Trimble Solutions Corporation, Espoo. Finland. Tekla, 2016c. Lamprell. Trimble Solutions Corporation, Espoo. Finland.

Teo, E. A. L., Ofori, G, Tjandra , I K and Kim, H, 2015. The potential of Building Information Modelling (BIM) for improving productivity in Singapore construction In: Raidén, A B and Aboagye - Nimo, E (Eds) Procs 3 st Annual ARCOM Conference, 7-9 September 2015, Lincoln, UK, Association of Researchers in Construction Management,661-670.

Tiruneh, H.W., Stetler, L.D., Oberling, Z.A., Morrison, D.R., Connolly, J.L. and Ryan, T.M., 2013, January. Discontinuity mapping using Ground-Based LiDAR: Case study from an open pit mine. In 47th US Rock Mechanics/Geomechanics Symposium. American Rock Mechanics Association.

TPA, 2015. E/A Design Division BIM Standard. The Port Authority of NY \& NJ Engineering Department, New York, United States.

Truijens, M., Wang, X., de Graaf, H. and Liu, J.J., 2014. Evaluating the performance of absolute rssi positioning algorithm-based microzoning and rfid in construction materials tracking. Mathematical Problems in Engineering, 2014.

Turrini, C., Lacombe, O. and Roure, F., 2014. Present-day 3D structural model of the Po Valley basin, Northern Italy. Marine and Petroleum Geology, 56, pp.266-289.

USACE, 2012. Roadmap for Life-Cycle BIM, United States Army Corps of Engineers, Washington DC, USA.

Veyber, V., Kudinov, A. and Markov, N., 2012. Model-driven platform for oil and gas enterprise data integration. International Journal of Computer Applications, 49(5). 
Walnum, H.T., Nekså, P., Nord, L.O. and Andresen, T., 2013. Modelling and simulation of $\mathrm{CO} 2$ (carbon dioxide) bottoming cycles for offshore oil and gas installations at design and off-design conditions. Energy, 59, pp.513-520.

Wang, J., Wang, X., Shou, W. and Xu, B., 2014. Integrating BIM and augmented reality for interactive architectural visualisation. Construction Innovation, 14(4), pp.453-476.

Wang, X., Yung, P., Luo, H. and Truijens, M., 2014a. An innovative method for project control in LNG project through 5D CAD: A case study. Automation in Construction, 45, pp.126-135.

Wang, X., Truijens, M., Hou, L., Wang, Y. and Zhou, Y., 2014b. Integrating Augmented Reality with Building Information Modeling: Onsite construction process controlling for liquefied natural gas industry. Automation in Construction, 40, pp.96-105.

Wang, J., Zhang, X., Shou, W., Wang, X., Xu, B., Kim, M.J. and Wu, P., 2015. A BIM-based approach for automated tower crane layout planning. Automation in Construction, 59, pp.168-178.

Wang, J., Sun, W., Shou, W., Wang, X., Wu, C., Chong, H.Y., Liu, Y. and Sun, C., 2015. Integrating BIM and LiDAR for real-time construction quality control. Journal of Intelligent \& Robotic Systems, 79(3-4), pp.417-432.

Wang, J., Wang, X., Shou, W., Chong, H.Y. and Guo, J., 2016. Building information modeling-based integration of MEP layout designs and constructability. Automation in Construction, 61, pp.134-146.

Wang, J., Shou, W., Wang, X. and Wu, P., 2016. Developing and evaluating a framework of total constraint management for improving workflow in liquefied natural gas construction. Construction Management and Economics, pp.1-16.

Ward, D., Butler, C., Khan, S. and Coyle, B., 2014, August. Corrib onshore gas pipeline, Ireland-using BIM on a large infrastructure project. In Proceedings of the Institution of Civil Engineers-Civil Engineering (Vol. 167, No. 3, pp. 123-130). Thomas Telford Ltd.

WinPCS, 2014a. North Rankin Redevelopment Project - Setting new benchmarks for integrating offshore greenfield and brownfield production facilities, Complan.

WinPCS, 2014b. Jansz-Io Subsea Pipeline Scarp Crossing, Complan. 
WinPCS, 2014c. PNG LNG Project starts first production ahead of schedule, Complan.

Xie, Y. and Ma, Y., 2015. Design of a multi-disciplinary and feature-based collaborative environment for chemical process projects. Expert Systems with Applications, 42(8), pp.4149-4166.

Xu, X.H., Peng, G., Liu, X.F., and S.Y.L., 2012, August. Oil and Gas Exploration Information Integration Management Plan Based on GIS Technology. In Computational and Information Sciences (ICCIS), 2012 Fourth International Conference on (pp. 526-529). IEEE.

Xue, C., 2015. Technology Integration Capability in the Oil/Gas Industry: Cross case study of iRing and BIM (Doctoral dissertation, TU Delft, Delft University of Technology).

Zeinalzadeh, A., Moussavi-Harami, R., Mahboubi, A. and Sajjadian, V.A., 2015. Basin and petroleum system modeling of the Cretaceous and Jurassic source rocks of the gas and oil reservoirs in Darquain field, south west Iran. Journal of Natural Gas Science and Engineering, 26, pp.419-426.

Zhang, X.W.and Zhang, J., 2012. Research on the Grid-based Production Management System for Digital Oil Field. International Journal of Digital Content Technology \& its Applications, 6(8), pp.80-88.

Zhou, J., Love, P.E.D., Matthews, J., Carey, B. and Sing, C.P., 2015. Objectoriented model for life cycle management of electrical instrumentation control projects. Automation in Construction, 49, pp.142-151.

Zhou, Y., Ding, L., Wang, X., Truijens, M. and Luo, H., 2015a. Applicability of 4D modeling for resource allocation in mega liquefied natural gas plant construction. Automation in Construction, 50, pp.50-63.

Zhu, L., Liu, X., He, S., Shi, J. and Pang, M., 2015. Keywords co-occurrence mapping knowledge domain research base on the theory of Big Data in oil and gas industry. Scientometrics, 105(1), pp.249-260.

Zhu, L.F., Li, M.J., Li, C.L., Shang, J.G., Chen, G.L., Zhang, B. and Wang, X.F., 2013. Coupled modeling between geological structure fields and property parameter fields in 3D engineering geological space. Engineering Geology, 167, pp.105-116. 
Zhu, L.F., Wang, X.F. and Zhang, B., 2014. Modeling and visualizing borehole information on virtual globes using KML. Computers \& Geosciences, 62, pp.62-70. 